\title{
Regime Types and Terrorism
}

\section{Khusrav Gaibulloev, James A. Piazza, and Todd Sandler}

\begin{abstract}
Regime type has opposing effects on terrorism. If a regime constrains the executive branch, then terrorism may be more prevalent. If, however, a regime allows all viewpoints to be represented, then grievances may be held in check, resulting in less terrorism. Regimes that value constituents' lives and property will also act to limit attacks. We formulate a game-theoretic model, containing a terrorist group and targeted government, that captures these opposing forces and supports a nonlinear relationship between regime type and terrorism. This model indicates how diverse samples in the literature can result in different relationships between regime type and terrorism. Seldom does it support the positive relationship that is prevalent in the terrorism literature. We apply a large variety of empirical techniques to show that regime type has a robust inverted U-shaped impact on various terrorism measures. Foreign policy variables (e.g., alliance with the United States) are not a robust influence on terrorism.
\end{abstract}

We live in a turbulent time with the Islamic State in Iraq and Syria (ISIS), al-Qaida in the Arabian Peninsula (AQAP), al-Shabaab, Boko Haram, and al-Qaida as significant terrorist movements to be reckoned with. Recent events indicate that such terrorist groups are gaining ground in emerging democracies, states in transition, and failing states (e.g., Iraq, Libya, and Syria). The 28 June 2016 suicide bombings and armed attack at the Istanbul airport underscore how these groups can strike outside their home country. Because targeted countries must decide on policy and action regarding autocracies and emerging democracies, it is essential that they know the consequences of regime type on terrorism. If, for instance, countries with intermediate ranges of democracy provide fertile environments for domestic and transnational terrorism, then efforts to promote fledgling democracies from autocracies must contend with enhanced terrorism in the short and medium run. ${ }^{1}$ This appears to be true for some "Arab Spring" countries (e.g., Libya, Egypt, and Tunisia). Even the fall of communism in Eastern Europe in the early 1990s ushered in greater terrorism in some transition countries as political rights, civil liberties, and other freedoms grew. At a minimum, knowledge of the terrorism downside of partial democracies allows for better counterterrorism planning as regime transformation ensues.

We gratefully acknowledge the helpful comments of three anonymous reviewers and Jon Pevehouse on earlier drafts. Full responsibility for the content rests with the authors. Sandler acknowledges funding from the Vibhooti Shukla Endowment at the University of Texas at Dallas.

1. See, for example, Chenoweth 2013. 
A crucial issue in the study of terrorism is therefore the influence of regime type on terrorist attacks. Since the early 1980s, articles have investigated whether or not democracy encouraged or discouraged terrorist attacks. ${ }^{2}$ They argue that, on the one hand, democracies may foster terrorism through their concomitant freedoms and executive branch constraints; on the other hand, democracies may inhibit terrorism through their political access and decisive protection of lives and property. Similarly, autocratic regimes may promote terrorism through their failure to assuage grievances, but these regimes may also curb terrorism through restricted freedoms and draconian counterterrorism measures. Despite myriad empirical studies on the impact of regime type on terrorism, findings are very mixed and inconclusive. The empirical literature on this topic is fragmented with different sample countries, diverse time periods, alternative terrorism types, and varied methodologies. The overwhelming number of empirical investigations introduced regime as a linear covariate and did not account for unobserved heterogeneity in their panel estimations. To date, there is no unifying framework that accounts for the whole spectrum of regime types and alternative functional forms when analyzing the relationship between regimes and terrorism. There is also no formal game-theoretic framework that provides a firm theoretical foundation for the opposing influences of regime types on terrorism that are discussed in the literature. ${ }^{3}$

Our formal model is an essential innovation in part because it indicates that the sample composition may give rise to alternative relationships between regime and terrorism. That is, a sample dominated by strong democracies is expected to have a negative relationship, while a sample dominated by fledgling democracies and anocracies is expected to have a positive relationship.

To address these and other shortcomings of the literature, we first formulate a twoplayer game-theoretic model that captures strategic, political access, and other influences that drive the impact of regime type on terrorism. These opposing drivers give rise to an inverted $\mathrm{U}$-shaped relationship between regime types and terrorism wherein some middle range of anocracy is most conducive to terrorism. Second, we apply a wide range of empirical methods-for example, pooled and random-effects negative binomial, fixed-effects negative binomial, zero-inflated negative binomial, Poisson, and instrumental variables approaches-to establish that regime type has an extremely robust inverted U-shaped relationship to terrorism for a global sample. ${ }^{4}$ This relationship holds for domestic and transnational terrorism. For the latter, the relationship applies both to the venue country and the perpetrators' home countries. To establish the inverted U-shaped relationship for the negative binomial estimates in the presence of our quadratic regime variable, we rely on margin-based semi-elasticity plots. Throughout our empirical investigation, we have a rich set of

2. See, for example, Eubank and Weinberg 1994; Eyerman 1998; and Hamilton and Hamilton 1983.

3. A game-theoretic framework accounts for the strategic interaction of terrorists and their targeted government.

4. We are interested in determining how regime type, rather than intra-regime features (e.g., parliamentary or presidential), influences terrorist attacks. 
controls, consistent with the literature. ${ }^{5}$ Given our myriad estimators and terrorism measures, our analysis is the most exhaustive study to date on this important topic. Previous articles employ only a few estimators applied to one or two terrorism measures. We even include a novel means for addressing endogeneity.

Third, our paper establishes the robustness of the inverted U-shaped relationship that characterized only a handful of earlier studies and makes a major contribution by showing that an inverted U-shaped relationship between democracy and terrorism applies to alternative terrorism variables and alternative measures of democracy over an extended time period for the two main terrorism event data sets. This includes indicators of regime, other than the Polity scale, such as the Freedom House political rights measure and Vanhanen measure of political participation. ${ }^{6}$

\section{Literature Review}

There are two established views about the influence of democracy on terrorist attacks in the venue country, where the incident occurs. Eyerman's "strategic influence" argues that democracies facilitate terrorism by reducing its marginal cost to the perpetrators through freedom of association, freedom of movement, protection of civil liberties, access to potential targets, and rights to due process. ${ }^{7}$ Freedom of the press in democracies even provides terrorists with the publicity that they seek for their causes. ${ }^{8}$ Owing to these freedoms and rights, the strategic influence argument predicts that democracies will sustain more terrorist attacks. The strategic line of thinking does not, however, account for the enhanced ability of well-established democracies to respond to exigencies to protect their citizens' lives and property, which, in turn, can limit terrorism. ${ }^{9}$ We add this protection factor to our analysis. The second or "political access" viewpoint argues that democracies are best able to assuage grievances by fostering greater political participation by a wide segment of society. ${ }^{10}$ Because they are politically inclusive, democracies will experience fewer terrorist attacks by giving all viewpoints a voice and fostering nonviolent modes of political activism. ${ }^{11}$ Consequently, political access predicts that democracy is a negative influence on terrorist attacks in a country by limiting terrorists' derived marginal utility. Strategic concerns, liberal democratic protections, and political access

5. See, for example, Gassebner and Luechinger 2011.

6. Freedom House 2014.

7. Eyerman 1998; and Schmid 1992.

8. Eubank and Weinberg 1994; Wilkinson 1986.

9. Doyle 1997 and Wilkinson 1986 emphasized that the legitimacy of liberal democracies rests on their ability to protect lives and property. This is also the case of the casualty aversion literature. See, for example, Pape 2003; and Valentino, Huth, and Croco 2010 who argued that voter accountability makes democracies limit casualties.

10. Eyerman 1998.

11. However, Aksoy and Carter 2014 argued that terrorist groups without an interest in within-system inclusion may be unaffected by political access. 
arguments explain terrorist attacks in the venue country, be they domestic or transnational attacks. These viewpoints may also provide insights into transnational terrorist attacks perpetrated by foreigners who are influenced by these same opposing forces in their resident country. That is, perpetrators' ability to prepare and execute an attack abroad depends on their home country's safeguards against terrorism, its freedom of association, its civil liberties, and its freedom of movement. Greater political access at home may ameliorate grievances before they spill over to an attack abroad. In short, the three regime-based drivers of terrorism (two from the literature and one we generated) are not only applicable to home-grown domestic terrorism, but also to transnational terrorism, for example, where a citizen attacks a foreigner for political motives. Unlike domestic terrorism, transnational terrorist incidents involve more than one country through their victims, perpetrators, and/or venue.

The empirical literature is mixed in its findings about the influence of democracy on terrorist attacks. The majority of studies, unlike ours, found a positive relationship between democracy and terrorism, which would seem to lend support to the strategic view. ${ }^{12}$ A minority of studies uncovered a negative relationship between democracy and terrorism, consistent with the political access hypothesis. ${ }^{13}$ Still others found no significant relationship between democracy and terrorism. ${ }^{14}$ Finally, the empirical analysis of a only few studies for a specific terrorism measure, a single democracy measure, and relatively short time period suggested an inverted U-shaped relationship, in which some intermediate level of democracy is most conducive to terrorist attacks. ${ }^{15}$

The variety of results may stem from the different forms of terrorism analyzed, alternative empirical estimators used, different time periods included, or diverse measures of democracy employed. Most articles investigated transnational terrorism leveled against a venue country. ${ }^{16}$ Some articles examined the effect of democracy on terrorism based on the perpetrators' home-country regime. ${ }^{17}$ Other articles investigated domestic and/or "total terrorism." 18 In recent years, studies involving domestic terrorism were made possible, in part, by the partitioning of the Global Terrorism Database (GTD $)^{19}$ into domestic, transnational, and unclassified terrorist incidents. ${ }^{20}$

12. See, for example, Chenoweth 2010, 2013; Dreher and Fischer 2010; Eubank and Weinberg 1994; Lai 2007; Li and Schaub 2004; Piazza 2007, 2008; and San-Akca 2014.

13. See, for example, Eyerman 1998; Hamilton and Hamilton 1983; and Ross 1993.

14. See Gassebner and Luechinger 2011; and Savun and Phillips 2009.

15. See Abadie 2006; Bandyopadhyay and Younas 2011; Drakos and Gofas 2006; and KurrildKlitgaard, Justesen, and Klemmensen 2006. With a quadratic specification, Testas 2004 found a Ushaped relationship between transnational terrorism and democracy for thirty-seven Muslim countries between 1968 and 1991, based on Freedom House measures. This is opposite to our results, which is also the case of Wade and Reiter 2007. These studies have only one or two terrorism measures and a limited sample period.

16. See Eubank and Weinberg 1994; Eyerman 1998; and Li 2005.

17. See, for example, Gassebner and Luechinger 2011.

18. See, for example, Conrad, Conrad, and Young 2014; San-Akca 2014; Savun and Phillips 2009; and Wilson and Piazza 2013.

19. National Consortium for the Study of Terrorism and Response to Terrorism 2014.

20. Enders, Sandler, and Gaibulloev 2011. 
Most articles with democracy as a determinant of the count of terrorist attacks did not use country fixed effects to control for individual countries' idiosyncrasies in their panel estimations. ${ }^{21}$ In instances when country fixed effects were employed, key democratic variables turned insignificant. For example, Chenoweth found that executive constraints, press freedom, and political participation were not significant for her country-fixed-effects estimates. ${ }^{22}$ In numerous studies, country fixed effects were estimated in robustness runs but then not reported. ${ }^{23}$

Studies of democracy's impact on terrorism also differed by their country sample and time period. Many essential studies used a sample period-the 1970s to the late 1990 s - that coincided with the dominance of leftist terrorists. ${ }^{24}$ Such studies did not include the post-1990s when religiously motivated terrorism had risen to prominence. ${ }^{25} \mathrm{We}$ suspect that this is a consequential limitation, given that many leftist terrorist movements were based in and active in democracies, which is not the case for religious fundamentalist movements. Thus, studies with pre-2000 sample periods are more apt to be associated with a positive relationship between democracy and terrorism.

Alternative measures of democracy were employed in past studies, many of which used Polity's measure of democracy. ${ }^{26}$ Others used Freedom House measures of political rights and civil liberties. Many studies on the relationship between democracy and terrorism treated democracy as a dummy variable to denote partly democratic and democratic regimes. ${ }^{27}$ Some studies relied upon disaggregated measures of democracy. For example, $\mathrm{Li}^{28}$ used executive constraint to capture the strategic influence, ${ }^{29}$ and political participation to proxy the political access influence.

Other recent articles distinguished alternative forms of autocracies-for example, dictatorship with opposition political parties, military dictatorships, single-party dictatorship, and dynastic monarchies - to ascertain how their differing governing and political institutions influence the predicted counts of terrorism. According to Wilson and Piazza, dictatorships that rely on coercion (e.g., military dictatorships) are more prone to terrorism, while dictatorships that can use more co-option (e.g., single-party dictatorships) are less inclined to terrorism. ${ }^{30}$ Similarly, Conrad, Conrad, and Young showed that autocracies with greater audience costs, such as military dictatorship and dynastic monarchies, experienced more terrorism. ${ }^{31}$ Audience

21. See, for example, Drakos and Gofas 2006; Lai 2007; Piazza 2007, 2008; San-Akca 2014; and Savun and Phillips 2009.

22. Chenoweth 2010.

23. Lai 2007.

24. See, for example, Eubank and Weinberg 1994; Eyerman 1998; and Li 2005.

25. Gaibulloev and Sandler 2014.

26. Marshall, Gurr, and Jaggers 2014.

27. See, for example, Eubank and Weinberg 1994; Gassebner and Luechinger 2011; Li 2005; Piazza 2008; and Savun and Phillips 2009.

28. Li 2005.

29. Vanhanen and Lundell 2014.

30. Wilson and Piazza 2013.

31. Conrad, Conrad, and Young 2014. 
costs stem from policy-generated discontentment among individuals who can act to remove a leader. ${ }^{32}$ According to Aksoy, Carter, and Wright, in a dictatorship, the presence of opposition parties without an elected legislature results in more terrorism because there is no other way to elicit change among aggrieved groups. ${ }^{33}$ These studies suggest that autocracies should not be treated as monolithic structures when it comes to terrorism. As autocracies assume more features of democracies, terrorism may increase. ${ }^{34} \mathrm{~A}$ continuum from autocracy to democracy may yield an inverted U-shaped relationship between regime type and terrorism, where some intermediate type of regime is associated with the most terrorism. That is, very stringent autocracies can coerce compliance, whereas the most democratic states can co-opt grievances while maintaining order.

There are at least two reasons that scholars have frequently found a positive, linear relationship between regime type and terrorism. First, studies that examined terrorist attacks prior to the 1990s oversampled the impact of terrorism in the democratic countries of Western Europe and North America. Second, the distribution of terrorist attacks since 1970 had a distinct rightward skew within the body of anocracies or hybrid regimes. For example, while anocracies scoring between -5 and 0 on the Polity 2 scale experienced on average 6.4 domestic terrorist attacks per year, the group of anocracies with more democratic features-those scoring between 0 and 5 on Polity-experienced 13.6 attacks. Both of these features make it appear that democracies experienced more terrorism when a linear model is fitted for only certain time periods or uniformly across all regime types. Our nonlinear estimates escape these biases.

In a well-known article, Hegre and colleagues found an inverted U-shaped relationship between regime type and civil war onset. ${ }^{35}$ Since Findley and Young ${ }^{36}$ found that terrorist attacks and civil war may overlap spatially and temporally, we must distinguish our inverted U-shaped relationship between regime type and terrorism from the inverted U-shaped relationship of Hegre and others. ${ }^{37}$ The civil war literature tests the structural conditions in countries that might be associated with the most basic marker of the phenomenon: the onset of civil conflict. In contrast, the theoretical framework of our study focuses on the tactical choices adopted by political actors, given the costs and opportunities afforded to them by regime type. Consequently, our dependent variable is a count of the total of all terrorist acts in the country and not just the onset of such acts. Another crucial difference is that most terrorist attacks do not occur in civil-war-torn countries. During our sample period, over 70 percent of all terrorist attacks occurred in countries that did not experience a civil

32. Weeks 2008.

33. Aksoy, Carter, and Wright 2012.

34. Wilson and Piazza 2013.

35. Hegre et al. 2001.

36. Findley and Young 2012.

37. Hegre et al. 2001. See, for example, Cederman, Hug, and Krebs 2010. 
conflict. The same holds true if we examine the nationality of perpetrators of transnational attacks. This realization provides us with an important test in the robustness discussion, where we establish our inverted U-shaped relationship for countries not experiencing civil wars. Finally, the sets of controls for civil war onset and terrorism counts differ markedly.

\section{Why the Inverted U-shaped Relationship}

We build a fully integrated game-theoretic model that captures three distinct regimebased influences-strategic, democratic protection, and political access-that affect the number of terrorist attacks. Because one of these influences works counter to the other two, a regime's effect on terrorism must account for the net impact of these opposing forces. This net effect is settled when either the strategic restraints dominate for strict autocracy or the political access and democratic protection influences dominate for full democracy. Liberal democratic ideals result in more counterterrorism when lives and property matter.

Before presenting our formal model, we further distill the theoretical logic for the inverted U-shaped relationship, where the largest amount of terrorism characterizes some intermediate level of anocracy and the smallest amounts of terrorism characterize full democracy and strict autocracy. In strict autocracy, terrorists have little strategic opportunity to engage in terrorism despite grievances generated from the absence of political access. Strict autocracies keep terrorism in check by rigorously limiting freedoms and strategic opportunities. Any sign of dissent is dealt with in a draconian manner. In anocracies by contrast, would-be terrorists possess greater strategic avenues to engage in terrorism. Anocracies are also associated with limited political access and the means to express grievance that may erupt in terrorism. Because anocracies possess less inherent commitment than democracies to protect lives and property, there are fewer checks on terrorist attacks. Thus, anocracies present the ideal environment for terrorism. As anocracies move to greater democracy or autocracy, forces to curb terrorism are better enabled. In a full democracy, the two driving forces are the lack of grievances owing to significant political access and the protection of lives and property owing to liberal democratic principles. ${ }^{38}$ Democratic principles cause governments to pursue counterterrorism measures (so that every level of attack is met with more counterterrorism effort compared to less democratic regimes) and to cut back on some civil liberties to reduce strategic factors favorable to terrorism. In consequence, terrorism is greatest for anocracies and smallest in full democracies and strict autocracies, thus giving rise to the inverted U-shaped relationship, contrary to the terrorism literature's general presumption of a positive linear relationship between regime type and terrorism. 


\section{Game-theoretic Model}

We put forward a two-player game. ${ }^{39}$ Both players move simultaneously. The terrorist group determines its attacks, $a$, and the government fixes its counterterrorism efforts, $e$. The terrorist group's problem involves choosing attacks to maximize the difference between its utility, $u$, or payoffs and the costs, $c$, of its terrorist campaign:

$$
\max _{a}[u(a, \delta)-c(a, e, \delta)] .
$$

In equation (1), utility increases at a diminishing rate with attacks so that $u_{a}>0$ and $u_{a a}<0 .{ }^{40}$ By assuaging grievances through political access or voice, the marginal utility of attacks falls with enhanced democratic principles, $\delta$, so that $u_{a \delta}<0$. The sign of this cross-partial captures the political access influence of greater democracy. The democratic index varies between 0 for a strict autocracy and 1 for the most democratic regime possible. Democratic principles augment the terrorist group's utility by having its views aired. The terrorist group's costs rise at an increasing rate with the number of attacks and the amount of counterterrorism so that $c_{a}>0, c_{e}>0, c_{a a}>0$, and $c_{e e}>0$. In addition, the marginal costs of conducting terrorist attacks increase as the government expends more counterterrorism efforts-that is, $c_{a e}>0$. The sign of the cross-partial also follows from greater efforts to root out the terrorists. Based on the strategic hypothesis, the marginal costs of conducting attacks fall (rise) as the regime embraces more (less) democratic values, that is, $c_{a \delta}<0$, because freedoms and executive constraints foster a more favorable attack environment.

The first-order condition (FOC) associated with maximizing equation (1) is

$$
u_{a}-c_{a}=0,
$$

which requires the terrorist group to choose its attack level to equate its resulting marginal utility and marginal costs. Equation (2) can be used to express the group's best response for attacks, $B R^{T}$, in terms of the government's counterterrorism measures: $B R^{T}=a(e)$. This follows because both expressions on the left-hand side of equation (2) are themselves functions of attacks and counterterrorism measures. By the implicit function rule, we can find the slope of the terrorist group's best-response curve to be

$$
\frac{\partial a}{\partial e}=\frac{\partial B R^{T}}{\partial e}=-\frac{-c_{a e}}{u_{a a}-c_{a a}}=\frac{c_{a e}}{u_{a a}-c_{a a}}<0
$$

39. Our model is similar in structure to that of Dragu 2011 and Siqueira and Sandler 2006. Dragu investigated privacy and intelligence, while Siqueira and Sandler examined the competition for grassroots support. Neither exercise had an overall democracy measure. The objective functions for the two players differed among the three analyses. For one measure of civil liberties, Dragu finds an inverted U-shaped relationship between privacy and terrorism. However, he does not consider political access or democratic protection of lives. He also distinguishes between the objective of the counterterrorism agency and that of the public.

40. Partial derivatives are indicated with subscripts, so that $u_{a}=\partial u / \partial a$ and $u_{a a}=\partial^{2} u / \partial a^{2}$. 
wherein the denominator is negative and the numerator is positive based on earlier assumptions. Thus, the terrorist group's reaction path is negatively sloped when $e$ is on the vertical axis and $a$ is on the horizontal axis. Intuitively, the terrorist group reacts with smaller attack levels as the government increases its counterterrorism, which denotes strategic substitutes.

Next, we investigate shifts in the terrorist group's reaction path as the level of democratic principles increase in the targeted regime. Applying the implicit function rule to equation (2) for a change in $\delta$, we have

$$
\frac{\partial B R^{T}}{\partial \delta}=\frac{c_{a \delta}-u_{a \delta}}{u_{a a}-c_{a a}} \frac{<}{<} .
$$

If the strategic hypothesis (S) is the driving influence, then $\partial B R^{T} / \partial \delta>0$ because $\left|c_{a \delta}\right|>\left|u_{a \delta}\right|$, as marginal cost savings exceed the gains from greater political access, thereby encouraging terrorist attacks. In this scenario, the terrorist group's bestresponse curve shifts up to the right, thus increasing the equilibrium level of attacks, as Figure 1 displays. If, however, the political access (PA) consideration

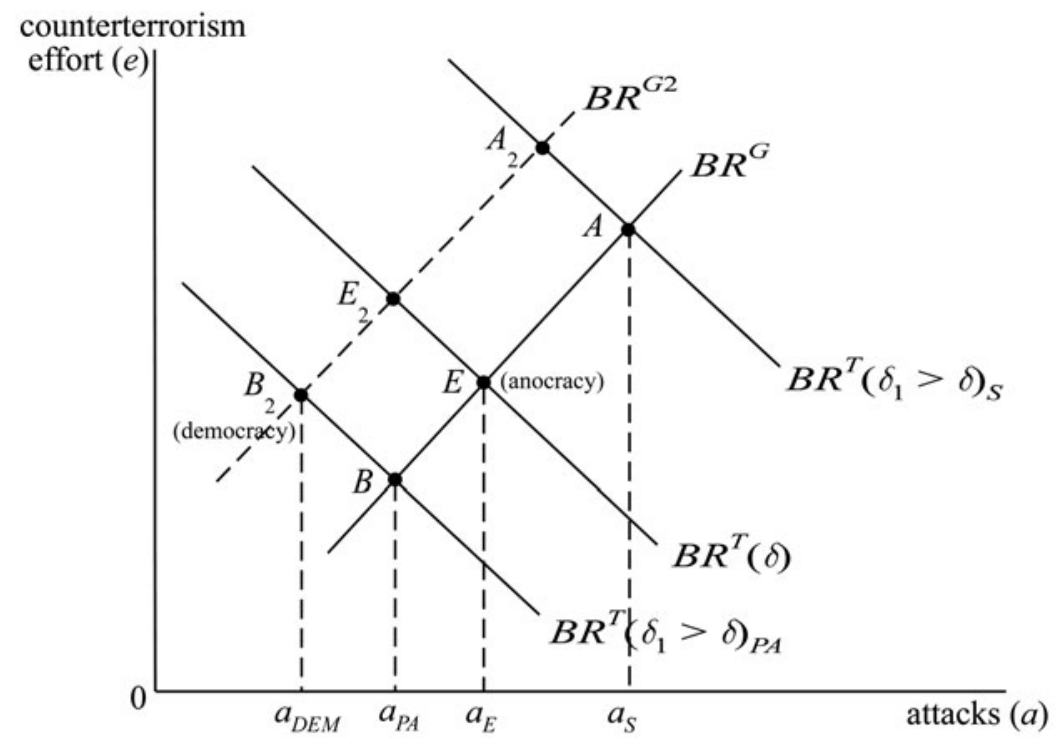

Notes: $B R^{G}$ is a government's best-response path; $B R^{G 2}$ is a government's best-response path when democracy increases; $B R^{T}(\delta)$ is the terrorists' best-response path for a given level of democracy; $B R^{T}\left(\delta_{1}>\delta\right)_{P A}$ is the terrorists' best-response path for greater democracy and political access dominance; $B R^{T}\left(\delta_{1}>\delta\right)_{S}$ is the terrorists' best-response path for greater democracy and strategic influence dominance; $E$ is the original Nash equilibrium for an anocracy; and $B_{2}$ is a likely equilibrium for a full democracy and political access dominance.

FIGURE 1. Comparative statics and comparison of attacks for anocracy versus full democracy 
dominates as grievances are alleviated through greater voice and participation, then the group's best-response path shifts down to the left, thereby reducing the equilibrium level of attacks. In this latter scenario, $\left|u_{a \delta}\right|>\left|c_{a \delta}\right|$, so that $\partial B R^{T} / \partial \delta<0$.

The targeted government's problem is to minimize the sum of its terrorist-induced losses, $l$, and counterterrorism expenditures, $C$, as indicated by

$$
\min _{e}[\delta l(e, a)+C(e)] \text {. }
$$

In equation (5), terrorism-induced losses are weighted by the democracy index, which illustrates that a liberal democracy, unlike a strict autocracy, is concerned with the protection of its constituency's lives and property. ${ }^{41}$ This important "protection" effect is missing in all previous theoretical discussions and justifies smaller amounts of terrorism in strong democracies by reinforcing the political access effect associated with such democracies, thereby providing stronger offsets to the strategic hypothesis to limit terrorist attacks. Government-perceived losses from terrorist attacks rise at an increasing rate, so that $l_{a}>0$ and $l_{a a}>0$. In contrast, counterterrorism efforts cut these losses ${ }^{42}$ at a diminishing rate of reduction, so that $l_{e}<0$ and $l_{e e}>0$. It is reasonable to assume that counterterrorism also limits the marginal losses from terrorist attacks, so that $l_{e a}<0$. As is standard with costs functions, counterterrorism costs increase at an increasing rate-that is, $C^{\prime}>0$ and $C^{\prime \prime}>0$.

The FOC associated with the government's minimization problem is

$$
\delta l_{e}+C^{\prime}=0
$$

wherein the weighted marginal reduced loss equals the marginal costs of counterterrorism. The government's best-response function is implicitly defined by equation (6) as $B R^{G}=e(a)$. To derive the slope of $B R^{G}$, we apply the implicit function rule to equation (6), which yields

$$
\frac{\partial B R^{G}}{\partial a}=-\frac{\delta l_{e a}}{\delta l_{e e}+C^{\prime \prime}}>0,
$$

since $l_{e a}<0$ and the denominator is positive. Hence, the government's counterterrorism reaction path is upward sloping, indicating that a larger terrorist campaign is met with more counterterrorism indicative of strategic complements. ${ }^{43}$ This positive slope agrees with targeted democratic countries' observed reaction to augment their counterterrorism efforts in response to greater terrorist attacks. For example, France enhanced countermeasures after the Paris armed attacks in November 2015.

Next, we derive the comparative statics influence of enhanced democratic principles on counterterrorism actions. By the implicit function rule applied to equation (6),

41. See Doyle 1997; and Wilkinson 1986.

42. A primary purpose of counterterrorism is to mitigate losses given a terrorist attack. US Department of Homeland Security 2011, 8.

43. It is reasonable not to treat the adversaries symmetrically since they have different objectives and constraints. 
we have

$$
\frac{\partial B R^{G}}{\partial \delta}=-\frac{l_{e}}{\delta l_{e e}+C^{\prime \prime}}>0,
$$

so that enhanced democracy shifts $B R^{G}$ upward and to the left. ${ }^{44}$ This, in turn, means that greater democracy results in more counterterrorism for any given terrorist attack level. This democratic response, not captured by the strategic or political access hypotheses, reinforces the political access influence by giving another ground for democratic-induced reduction in terrorist attacks.

To illustrate the Nash equilibrium choice of $a$ and $e$ that simultaneously solves equations (2) and (6), we use Figure 1 heuristically. In Figure $1, B R^{T}(\delta)$ and $B R^{G}$ represent the terrorist group's and the government's respective best-response paths. Their intersection at point $E$ indicates the Nash equilibrium levels of counterterrorism and terrorist attacks. Insofar as our empirical analysis is interested in only the determinants of terrorist equilibrium attacks, $a_{E}$ is indicated on the horizontal axis. ${ }^{45}$ Initially, ignore the dashed line $B R^{G 2}$ in Figure 1. If the strategic influence dominates, then $B R^{T}$ shifts upwards and to the right, as shown, for a greater democracy index $\left(\delta_{1}>\delta\right)$, leading to a larger number of terrorist attacks $a_{S}>a_{E}$ at point $A$. If, however, the political access influence dominates, then $B R^{T}$ shifts downwards and to the left, resulting in a smaller level of terrorism at point $B$ where $a_{P A}<a_{E}$. Thus, we have a game-theoretic foundation for the two influences linking regime type to terrorism. Moreover, enhanced democracy also results in an upward shift of $B R^{G}$ to $B R^{G 2}$, which reduces terrorist attacks compared to the intersections displayed on $B R^{G}$. This is the "democratic protection" effect, previously absent from the literature.

If we ignore the terrorist group's reaction to enhanced democracy, then the shift of the government's reaction curve moves the equilibrium from $E$ to $E_{2}$, thus reducing attacks. When the responses of the targeted government and the terrorist group to enhanced democracy are included, the final equilibrium will be at either $A_{2}$ or $B_{2}$. In online Appendix A, we display the associated comparative statics mathematically.

An inverted U-shaped relationship may follow from our theory now. Return to Figure 1 and first consider just $B R^{G}$ and $B R^{T}$ as denoting the government's and terrorists' reaction paths for an anocracy, where Nash equilibrium attacks are $a_{E}$ at point $E$. Next, consider a full-fledged democracy such as the United States, Canada, or Japan. Compared to a typical anocracy, the full-fledged democracy's $B R^{G 2}$ curve is displaced leftward of $B R^{G}$ owing to stronger democratic protection of lives and property because each level of terrorist attacks is met with augmented counterterrorism relative to an anocracy. For instance, after the Brussels airport attack in March 2016, the Belgian government deployed greatly enhanced defensive and proactive counterterrorism measures. This included greater surveillance at border crossings. Moreover, the move to a full-fledged democracy away from anocracy shifts $B R^{T}$ in 
Figure 1 downward because political access considerations tend to overwhelm strategic factors in highly democratic countries. Such countries restrict civil liberties and freedoms to meet terrorist threats, as illustrated by the US Patriot Act following 9/11, and, in so doing, limit strategic offsets to political access. During the height of left-wing terrorism in Europe, affected countries constrained civil liberties to curb terrorism. ${ }^{46}$ A full-blown democracy's final equilibrium number of attacks is at $B_{2}$, where attacks, $a_{D E M}$, are smaller than $a_{E}$.

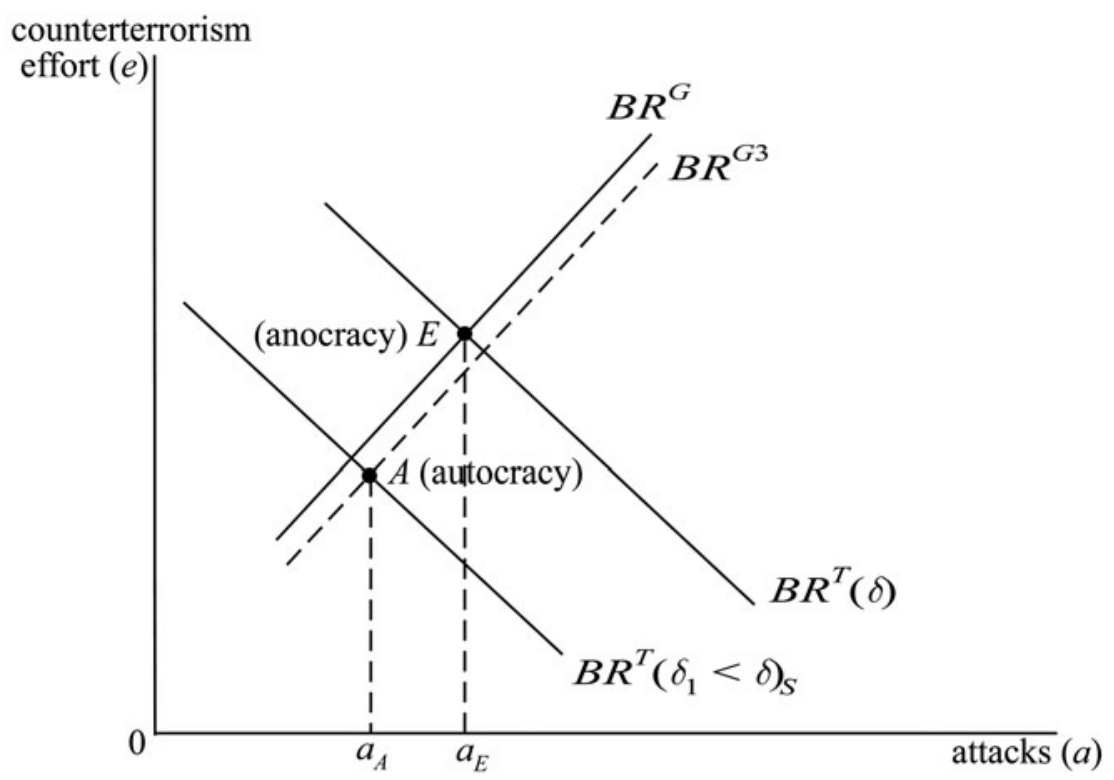

Notes: $B R^{G}$ is an anocracy's best-response path; $B R^{G 3}$ is an autocracy's best-response path; $B R^{T}(\delta)$ is the terrorists' best-response path in an anocracy; $B R^{T}\left(\delta_{1}<\delta\right)_{S}$ is terrorists' best-response path in an autocracy; $a_{A}$ is equilibrium attacks in an autocracy; and $a_{E}$ is equilibrium attacks in an anocracy.

FIGURE 2. Attack equilibrium in anocracy versus autocracy

Next, compare terrorist attacks in a typical anocracy and in a strict autocracy. In Figure 2, the primary change is a downward and leftward shift in $B R^{T}$ as autocracies rigorously inhibit and root out terrorist groups, resulting in reduced strategic facilitators-that is, an unfavorable environment for terrorist operations with greater marginal attack costs as a fall in $\delta$ raises $c_{a}$. For the terrorists, the downward-shifted $B R^{T}$ is for $\delta_{1}<\delta$ in Figure 2, where strategic factors are greatly reduced for the 
terrorists in a strict autocracy. While it is true that political access is reduced leading to grievances ( $B R_{P A}^{T}$ shifts up), the would-be terrorists do not have the right environment to express their grievances violently so that attacks should not increase by much or at all owing to reduced political access at the strict autocratic equilibrium relative to the anocratic equilibrium. Reduced strategic factors constitute the dominant influence on $B R^{T}$ for $\left(\delta_{1}<\delta\right)$ so that $B R^{T}$ shifts left and down, thus reducing attacks, $a_{A}$, relative to the anocratic equilibrium at $E$. Any downward shift in $B R^{G}$ is expected to be very limited (see $B R^{G 3}$ in Figure 2), given the anticipated small value of $\left|l_{e}\right|$ for a strict autocracy, where civilian lives do not much matter. During the Moscow theater siege in October 2002, the authorities gassed everyone to end the siege, thereby killing 130 hostages.

The fewest terrorist attacks are anticipated in both strict autocracies and full-fledged democracies. Anocracies lack the means to respond rigorously to terrorism and possess intermediate levels of political access and strategic facilitators; hence anocracies are expected to experience the most terrorism. As such, our analysis is consistent with an inverted U-shaped relationship between a regime continuum and terrorist attacks. ${ }^{47}$ This is true for domestic and transnational terrorism. For our data, we find that anocracies - for example, Algeria, Jordan, Nepal, Nigeria, Pakistan, and the Philippines - that contain weak forms of democratic and nondemocratic political institutions experienced a lot of domestic and transnational terrorism. In contrast, strong democracies-for example, the Scandinavian countries, the Benelux countries, Canada, Australia, and New Zealand-suffered less terrorism than anocracies. Moreover, strong autocracies-for example, China, the Eastern Bloc countries (before 1991), North Korea, and Vietnam-withstood less terrorism than anocracies.

\section{Data}

To empirically test the theoretical model, we construct a panel data set consisting of 159 countries for nine periods: 1970-1974, 1975-1979, 1980-1984, 1985-1989, 19901994, 1995-1999, 2000-2004, 2005-2009, and 2010-2012. The explanatory variables are averaged within each period. We implement fixed-effects estimators that explore the within-variations of variables for the mainstay of the analysis. ${ }^{48}$ Since regime-type variables change slowly over time, grouping years into periods allows us to obtain more accurate within-estimates of these variables. Military intervention data are available only through 2005. Annual analysis with this variable would exclude the entire sample data after 2005, while averaging allows us to make use of information until $2009 .{ }^{49}$ A robustness check with annual data supports our main conclusions.

47. This theoretical finding agrees with data displays in an interesting survey on democracy and terrorism by Chenoweth 2013, who presented data plots without empirical tests.

48. We also conduct estimations without country or year fixed effects and produce consistent results.

49. In those regressions where this variable is present, all information for 2010-2012 is dropped from the analysis. 
We use four measures of terrorism to construct four dependent variables, each of which consists of total counts of terrorist attacks for a country in a five-year period. The first two variables are five-year counts of domestic and transnational attacks derived from GTD through a decomposition process. ${ }^{50}$ The venue country is where the attack takes place. In our analysis, we simply label these two dependent variables GTD DOM and GTD TRANS. The other two measures of terrorism are derived from the International Terrorism: Attributes of Terrorist Events (ITERATE) database. ${ }^{51}$ Like GTD, ITERATE is an event database, but unlike GTD, ITERATE collects data on only transnational terrorist events. We allocate transnational terrorist attacks by country in two alternative ways: a count of ITERATE attacks sorted by the venue country and a count of ITERATE attacks sorted by the country of national origin of the perpetrators. We denote these dependent variables as ITERATE and ITERATE NAT. For the national origin variable, ITERATE codes the first three nationalities of the attack perpetrators. When an attack involves a perpetrator or perpetrators from only one country, we assign the attack to that country. If, however, an attack involves perpetrators from two or three countries, we allocate the attack to each of these countries. This double counts attacks but succeeds in our intention to trace attacks back to the country of national origin. In the robustness analysis, we also replace counts of attacks with the number of terrorist incidents with casualties for each variable.

Following previous studies we use several different measures of political regime. ${ }^{52}$ To examine the overall impact of regime type on terrorism, we rely on the Polity 2's composite score, ${ }^{53}$ an indicator that measures a country's regime type on a twentyone-point scale ranging from -10 , indicating that the regime is a complete autocracy, to +10 , indicating that the regime is a complete democracy. We first normalize this indicator so that it ranges between 0 and 1 and then compute its five-year averaged values to produce what we call the PoLiTy 2 variable in the estimations. Because we theorize that the relationship between regime type and terrorism may be nonlinear (i.e., that regimes in the intermediate range of the Polity continuum are most plagued by terrorism), we also obtain the squared value of PoLITY 2. Using five-year averaged Polity data, we also develop a series of dichotomous nominal variables for specific regime types following practices by Marshall and Gurr ${ }^{54}$ and Vreeland. ${ }^{55}$ These include dummy variables for democracies scoring a 6 and higher on Polity, autocracies scoring a -6 or lower on Polity, and anocracies scoring between 5 and -5 on Polity.

Additionally, we derive regime-type measurements from sources other than Polity. These include the Freedom House Political Rights measure, ${ }^{56}$ which is a seven-point

50. The process is that of Enders, Sandler, and Gaibulloev 2011.

51. Mickolus et al. 2014.

52. See Savun and Phillips 2009; and Wade and Reiter 2007.

53. Marshall, Gurr, and Jaggers 2014.

54. Marshall and Gurr 2003.

55. Vreeland 2008.

56. Freedom House 2014. 
indicator with 1 indicating that a country provides its citizens with full democratic rights, the Vanhanen measure of political participation, ${ }^{57}$ which quantifies the public's participation in national elections, and Polity's executive constraints indicator, which measures the degree to which executive power is held in check. Similar to Polity 2, we first normalize these indicators and then compute their five-year averaged values to obtain political rights (FHPR), political participation (VPP), and executive constraints (XCONST) variables and their squared terms. Li found that separate elements of regime type-VPP and XCONST indicators-affected terrorism. ${ }^{58}$ Therefore, we also add both VPP and XCONST in the same regression to evaluate their effects.

In our estimations to accompany regime type, we include other controls from previous studies of democracy and terrorism. Savun and Phillips ${ }^{59}$ theorized that democracies experienced more transnational terrorist attacks when they assumed a prominent interventionist role in international affairs. In some models, we therefore include proxies for their foreign policy measures-alliance ties with the United States, involvement in foreign policy crises, and intervention in civil wars. To augment the temporal range of observations, we apply slightly different foreign policy indicators. For an alliance with the United States, we use a dummy indicator, derived from Gibler updated through $2012 .{ }^{60}$ To measure countries' foreign interventions, we construct a count of interventions per year, derived from the International Military Interventions data set ${ }^{61}$ and extended through 2005 by Kisangani and Pickering. ${ }^{62}$ This measure ranges between zero and six interventions per country per year. For countries' involvement in international crises, we create a dichotomous variable based on the International Crisis Behavior (ICB) data set that is coded 1 for any observation where a country has experienced at least one international crisis during a three-year period. ${ }^{63} \mathrm{We}$ compute five-year averages of these measures as our variables.

In nearly all our estimated models, we include a set of indicators of country attributes used in other studies of terrorism. ${ }^{64}$ For the age of the current regime, we use the five-year averaged durable score from the Polity database. More durable regimes should experience few terrorist incidents. ${ }^{65} \mathrm{We}$ also include natural log versions of the country's average population (POP) and its average gross domestic product (GDP) per capita in all models. ${ }^{66}$ Population is typically positively associated with terrorism owing to greater exposure and potential recruits. Our expectations are agnostic with respect to GDP PER CAPITA as a determinant of terrorism, given mixed results in the

57. Vanhanen and Lundell 2014.

58. Li 2005.

59. Savun and Phillips 2009.

60. Gibler 2009.

61. Pearson and Bauman 1993.

62. Kisangani and Pickering 2008.

63. Wilkenfeld et al. 2010.

64. See, for example, Wade and Reiter 2007.

65. Eyerman 1998.

66. World Bank 2014. 
literature. ${ }^{67}$ To hold constant the general internal security climate that might induce terrorism, we include in the estimations the five-year averaged values of the magnitude score of episodes of civil war from Marshall. ${ }^{68}$ This is an ordinal measure ranging from 0 (no civil war) to 7 (severe civil war). For a state's material and military capacity that might curb terrorist activity or else prompt insurgents to shift away from conventional means toward terrorist attacks, we use the Composite Index of National Capacity (CINC) index score. This score combines population, metals production, energy consumption, and military expenditure and personnel. ${ }^{69}$

We also include measures of economic and political globalization. The first measures a country's integration in the global economy (e.g., its economic flows and restrictions) and the second measures its integration in the community of countries (e.g., its memberships in international organizations and treaties). ${ }^{70}$ Finally, our estimations include several controls employed by Savun and Phillips. ${ }^{71}$ Specifically, we control for ethnic group political discrimination but use a different measure than the one Savun and Phillips used. In particular, we employ the Ethnic Power Relations measure of the percentage of the population that faces political discrimination (DISCRIMINATED POP), based upon their ethnic group background. ${ }^{72}$ We control for the degree of ethnic fractionalization (E. FRACTIONALIZATION) within the country by theorizing that more ethnically diverse countries are more prone to contentious politics, conflict, and therefore more terrorist activity. Data for this variable are derived from Fearon's data on the probability that two individuals selected randomly from the population will be from different ethnic groups. ${ }^{73}$ To control for regional variation and idiosyncrasies, we include regional dummy variables for countries in Africa, the Americas, the Middle East and North Africa, and Asia in pooled and randomeffects regressions. The time-invariant variables, such as fractionalization and regional dummies, are not included in the fixed-effects panel regressions. A table of summary statistics is reported in online Appendix B.

\section{Methods}

Poisson and negative binomial regressions are two commonly used methods for estimating count data. ${ }^{74} \mathrm{We}$ apply these two estimators to a wide range of specifications of our terrorism model to ascertain the impact of regime change on the number of

67. See discussion in Enders, Hoover, and Sandler 2016.

68. Marshall 2015.

69. The CINC score is taken from the National Materials Capabilities data set (version 4.0), of the Correlates of War project, available at <http://www.correlatesofwar.org/data-sets/national-material-capabilities>, accessed 21 July 2014. See Singer, Bremer, and Stuckey 1972; and Singer 1987.

70. See Dreher 2006; and Dreher, Gaston, and Martens 2008.

71. Savun and Phillips 2009.

72. Wimmer, Cederman, and Min 2009 (database updated through 2010).

73. Fearon 2003.

74. Cameron and Trivedi 2013. 
terrorist events. We include the squared term of the regime type variable to capture a nonlinear relationship between a country's regime type and its terrorism, postulated by our theory. We run regressions both with and without fixed effects. In the fixedeffects regressions, country effects are added to account for the unobserved heterogeneities that are specific to each country. The time effects are entered to control for time-specific global shocks or systemic effects that might affect terrorism, such as the end to the Cold War or the post-9/11 era. These effects capture cross-sectional dependence to the extent that the impacts of common factors are the same across countries.

\section{Results}

To tell our main story we use a simple regression of terrorism on regime type, without any control variables. In Table 1, columns 2 to 5 display the standard pooled negative binomial (PNB) regression results for domestic terrorist events from GTD, transnational terrorist events from GTD, transnational terrorist attacks from ITERATE, and ITERATE incidents sorted by the perpetrators' country of national origin. Columns 6 to 9 present the fixed-effects negative binomial regression results. With Polity 2 being the only variable (panel A), the impact of democracy on terrorism is positive and generally significant in the PNB regressions. However, when country and time fixed effects are added, the impact of regime type is no longer statistically significant. These results agree with the mixed findings in the literature.

When we examine our nonlinear specification in panel B of Table 1, we see that the impact of the normalized PoLITY 2 score on the number of terrorist events is positive, whereas the effect of the squared term of the PoLITy 2 index is negative, implying an inverted U-shaped effect of the regime type on terrorism. The squared term is challenging to interpret in nonlinear models and we look deeper into this issue soon. This finding is statistically significant across most models and specifications.

We use numerous estimation approaches along with various specifications and robustness checks to ensure that our findings are not artifacts of a specific econometric approach. First, we estimate the standard PNB regression, which does not include country and time fixed effects. In Table 2, columns 2 to 5 display the pooled regression results for the four measures of terrorism.

The effect of POLITY 2 is positive, while the effect of POLITY 2 SQRD is negative, confirming our main finding from the baseline regressions. Given that the squared term is difficult to interpret in nonlinear models, we plot the predicted count of GTD transnational terrorist incidents evaluated at different values of the normalized PoLITY 2 score with 95 percent confidence intervals. See Figure 3. As this normalized PoLITY 2 score improves, the predicted number of attacks increases when this score is below 0.6 and decreases when this score exceeds 0.6 , thereby exhibiting the nonlinear pattern that our theoretical model predicts. The predicted counts are statistically significant. Approximately, autocracy corresponds to the normalized PoLITY 2 score of less than 0.23 and democracy corresponds to the PoLITy 2 score of more than 0.77 , 
TABLE 1. Baseline negative binomial regressions

\begin{tabular}{|c|c|c|c|c|c|c|c|c|}
\hline & GTD DOM & GTD TRANS & ITERATE & ITER NAT. & GTD DOM & GTD TRANS & ITERATE & ITER NAT. \\
\hline \multicolumn{9}{|l|}{ Panel A } \\
\hline Polity 2 & $\begin{array}{l}2.271 * * * \\
(0.467)\end{array}$ & $\begin{array}{l}1.519^{* * *} \\
(0.353)\end{array}$ & $\begin{array}{l}1.100 * * * \\
(0.310)\end{array}$ & $\begin{array}{c}0.714 \\
(0.439)\end{array}$ & $\begin{array}{c}0.647 \\
(0.515)\end{array}$ & $\begin{array}{c}0.733^{*} \\
(0.400)\end{array}$ & $\begin{array}{c}0.449 \\
(0.326)\end{array}$ & $\begin{array}{c}-0.076 \\
(0.402)\end{array}$ \\
\hline Country effects & No & No & No & No & Yes & Yes & Yes & Yes \\
\hline Time effects & No & No & No & No & Yes & Yes & Yes & Yes \\
\hline NT & 1327 & 1327 & 1327 & 1327 & 1327 & 1327 & 1327 & 1327 \\
\hline \multicolumn{9}{|l|}{ Panel B } \\
\hline Polity 2 & $\begin{array}{l}10.959 * * * \\
(1.531)\end{array}$ & $\begin{array}{l}4.717 * * * \\
(1.631)\end{array}$ & $\begin{array}{c}2.135 \\
(1.630)\end{array}$ & $\begin{array}{c}1.432 \\
(1.782)\end{array}$ & $\begin{array}{l}10.492 * * * \\
(1.973)\end{array}$ & $\begin{array}{l}8.207 * * * \\
(1.576)\end{array}$ & $\begin{array}{l}7.075^{* * *} \\
(1.313)\end{array}$ & $\begin{array}{l}8.004 * * * \\
(1.282)\end{array}$ \\
\hline POLITY 2 SQRD & $\begin{array}{l}-8.123 * * * \\
(1.461)\end{array}$ & $\begin{array}{c}-2.927^{* *} \\
(1.456)\end{array}$ & $\begin{array}{c}-0.943 \\
(1.499)\end{array}$ & $\begin{array}{c}-0.657 \\
(1.623)\end{array}$ & $\begin{array}{l}-9.438 * * * \\
(1.786)\end{array}$ & $\begin{array}{l}-7.139 * * * \\
(1.423)\end{array}$ & $\begin{array}{l}-6.386 * * * \\
(1.159)\end{array}$ & $\begin{array}{c}-7.776 \text { *** } \\
(1.115)\end{array}$ \\
\hline Country effects & No & No & No & No & Yes & Yes & Yes & Yes \\
\hline Time effects & No & No & No & No & Yes & Yes & Yes & Yes \\
\hline$N T$ & 1327 & 1327 & 1327 & 1327 & 1327 & 1327 & 1327 & 1327 \\
\hline
\end{tabular}

Notes: Cluster-robust (by country) standard errors are in parentheses. $N T$ is the sample size. $* p<.10 ; * * p<.05 ; * * * p<.01$. 
TABLE 2. Pooled and HHG's fixed-effects negative binomial regressions

\begin{tabular}{|c|c|c|c|c|c|c|c|c|}
\hline & \multicolumn{4}{|c|}{ Pooled negative binomial (PNB) } & \multicolumn{4}{|c|}{ HHG's fixed-effects negative binomial } \\
\hline & GTD DOM & GTD TRANS & ITERATE & ITER NAT. & GTD DOM & GTD TRANS & ITERATE & ITER NAT. \\
\hline Polity 2 & $\begin{array}{l}9.850 * * * \\
(2.023)\end{array}$ & $\begin{array}{l}9.166^{* * * *} \\
(1.513)\end{array}$ & $\begin{array}{c}4.232 * \\
(2.159)\end{array}$ & $\begin{array}{l}8.946 * * * \\
(1.488)\end{array}$ & $\begin{array}{l}5.891 * * * \\
(1.055)\end{array}$ & $\begin{array}{l}4.687 * * * \\
(1.006)\end{array}$ & $\begin{array}{l}2.990 * * * \\
(0.967)\end{array}$ & $\begin{array}{l}2.891 * * \\
(1.234)\end{array}$ \\
\hline POLITY 2 SQRD & $\begin{array}{c}-7.865 * * * \\
(1.772)\end{array}$ & $\begin{array}{c}-7.636^{* * * *} \\
(1.330)\end{array}$ & $\begin{array}{c}-3.840 * * \\
(1.869)\end{array}$ & $\begin{array}{c}-7.827 * * * \\
(1.340)\end{array}$ & $\begin{array}{c}-4.930 * * * \\
(0.966)\end{array}$ & $\begin{array}{c}-3.682 * * * \\
(0.854)\end{array}$ & $\begin{array}{l}-2.411 * * * \\
(0.809)\end{array}$ & $\begin{array}{c}-2.582 * * \\
(1.066)\end{array}$ \\
\hline US ALLIANCE & $\begin{array}{l}1.051^{* * * *} \\
(0.314)\end{array}$ & $\begin{array}{l}1.167 * * * \\
(0.277)\end{array}$ & $\begin{array}{l}1.108 * * * \\
(0.275)\end{array}$ & $\begin{array}{l}1.676^{* * * *} \\
(0.329)\end{array}$ & $\begin{array}{c}0.080 \\
(0.170)\end{array}$ & $\begin{array}{c}-0.158 \\
(0.249)\end{array}$ & $\begin{array}{c}-0.181 \\
(0.286)\end{array}$ & $\begin{array}{c}-0.176 \\
(0.291)\end{array}$ \\
\hline INTERVENTION & $\begin{array}{c}-0.093 \\
(0.222)\end{array}$ & $\begin{array}{c}-0.210 \\
(0.164)\end{array}$ & $\begin{array}{c}0.110 \\
(0.183)\end{array}$ & $\begin{array}{c}0.453^{*} \\
(0.239)\end{array}$ & $\begin{array}{c}-0.019 \\
(0.110)\end{array}$ & $\begin{array}{c}-0.026 \\
(0.099)\end{array}$ & $\begin{array}{c}0.007 \\
(0.124)\end{array}$ & $\begin{array}{c}0.139 \\
(0.159)\end{array}$ \\
\hline INTERNATIONAL CRISIS & $\begin{array}{l}1.418^{* * *} \\
(0.275)\end{array}$ & $\begin{array}{l}0.810^{* * * *} \\
(0.198)\end{array}$ & $\begin{array}{l}0.899 * * * \\
(0.210)\end{array}$ & $\begin{array}{l}0.812 * * * \\
(0.213)\end{array}$ & $\begin{array}{l}0.479 * * * \\
(0.136)\end{array}$ & $\begin{array}{c}0.294^{*} \\
(0.166)\end{array}$ & $\begin{array}{c}0.103 \\
(0.103)\end{array}$ & $\begin{array}{c}0.156 \\
(0.138)\end{array}$ \\
\hline DURABLE & $\begin{array}{c}0.001 \\
(0.004)\end{array}$ & $\begin{array}{l}0.007 * * \\
(0.003)\end{array}$ & $\begin{array}{c}0.003 \\
(0.004)\end{array}$ & $\begin{array}{c}0.008^{*} \\
(0.004)\end{array}$ & $\begin{array}{c}-0.000 \\
(0.003)\end{array}$ & $\begin{array}{c}0.000 \\
(0.005)\end{array}$ & $\begin{array}{c}-0.004 \\
(0.004)\end{array}$ & $\begin{array}{c}-0.001 \\
(0.005)\end{array}$ \\
\hline CIVIL WAR & $\begin{array}{l}0.419^{* * *} \\
(0.096)\end{array}$ & $\begin{array}{l}0.377 * * * \\
(0.077)\end{array}$ & $\begin{array}{l}0.336^{* * * *} \\
(0.084)\end{array}$ & $\begin{array}{l}0.448 * * * \\
(0.097)\end{array}$ & $\begin{array}{c}0.160^{*} \\
(0.092)\end{array}$ & $\begin{array}{l}0.183 * * \\
(0.078)\end{array}$ & $\begin{array}{c}0.116^{*} \\
(0.068)\end{array}$ & $\begin{array}{l}0.190 * * \\
(0.095)\end{array}$ \\
\hline DISCRIMINATED POP & $\begin{array}{l}2.017 * * \\
(0.837)\end{array}$ & $\begin{array}{l}1.906 * * * \\
(0.681)\end{array}$ & $\begin{array}{c}0.860 * \\
(0.521)\end{array}$ & $\begin{array}{l}2.188 * * * * \\
(0.633)\end{array}$ & $\begin{array}{c}0.245 \\
(0.528)\end{array}$ & $\begin{array}{r}-0.049 \\
(0.653)\end{array}$ & $\begin{array}{c}0.370 \\
(0.684)\end{array}$ & $\begin{array}{c}0.702 \\
(0.833)\end{array}$ \\
\hline LOG(GDP/POP) & $\begin{array}{c}0.088 \\
(0.139)\end{array}$ & $\begin{array}{c}0.130 \\
(0.114)\end{array}$ & $\begin{array}{l}0.250^{* *} \\
(0.114)\end{array}$ & $\begin{array}{c}0.166 \\
(0.120)\end{array}$ & $\begin{array}{l}0.244 * * \\
(0.109)\end{array}$ & $\begin{array}{l}0.272 * * * \\
(0.102)\end{array}$ & $\begin{array}{l}0.254 * * \\
(0.101)\end{array}$ & $\begin{array}{l}0.345^{* * *} \\
(0.119)\end{array}$ \\
\hline LOG(POP) & $\begin{array}{l}0.843^{* * * *} \\
(0.141)\end{array}$ & $\begin{array}{l}0.628^{* * *} \\
(0.108)\end{array}$ & $\begin{array}{l}0.438^{* * *} \\
(0.119)\end{array}$ & $\begin{array}{l}0.656^{* * * *} \\
(0.132)\end{array}$ & $\begin{array}{c}-0.002 \\
(0.096)\end{array}$ & $\begin{array}{c}0.127 \\
(0.109)\end{array}$ & $\begin{array}{c}0.165 \\
(0.135)\end{array}$ & $\begin{array}{c}0.026 \\
(0.143)\end{array}$ \\
\hline NATIONAL CAPABILITY & $\begin{array}{r}-10.167 \\
(6.834)\end{array}$ & $\begin{array}{c}-7.050 \\
(6.452)\end{array}$ & $\begin{array}{c}0.377 \\
(8.775)\end{array}$ & $\begin{array}{c}-2.728 \\
(6.709)\end{array}$ & $\begin{array}{c}1.572 \\
(8.421)\end{array}$ & $\begin{array}{r}-10.332 \\
(8.885)\end{array}$ & $\begin{array}{c}1.516 \\
(10.095)\end{array}$ & $\begin{array}{c}-3.241 \\
(6.846)\end{array}$ \\
\hline ECON. GLOBALIZATION & $\begin{array}{c}-0.006 \\
(0.009)\end{array}$ & $\begin{array}{c}-0.012^{*} \\
(0.007)\end{array}$ & $\begin{array}{c}-0.003 \\
(0.009)\end{array}$ & $\begin{array}{c}-0.008 \\
(0.008)\end{array}$ & $\begin{array}{c}-0.001 \\
(0.007)\end{array}$ & $\begin{array}{c}-0.003 \\
(0.008)\end{array}$ & $\begin{array}{c}-0.002 \\
(0.007)\end{array}$ & $\begin{array}{c}-0.024 * * \\
(0.010)\end{array}$ \\
\hline POLIT. GLOBALIZATION & $\begin{array}{c}-0.011 \\
(0.008)\end{array}$ & $\begin{array}{c}-0.009 \\
(0.006)\end{array}$ & $\begin{array}{c}-0.012 * * \\
(0.006)\end{array}$ & $\begin{array}{c}-0.022 * * * \\
(0.006)\end{array}$ & $\begin{array}{c}0.008 \\
(0.006)\end{array}$ & $\begin{array}{c}0.009 \\
(0.007)\end{array}$ & $\begin{array}{c}0.004 \\
(0.006)\end{array}$ & $\begin{array}{c}0.008 \\
(0.008)\end{array}$ \\
\hline E. FRACTIONALIZATION & $\begin{array}{c}-0.411 \\
(0.492)\end{array}$ & $\begin{array}{c}-0.263 \\
(0.380)\end{array}$ & $\begin{array}{c}-0.209 \\
(0.389)\end{array}$ & $\begin{array}{c}-0.110 \\
(0.433)\end{array}$ & & & & \\
\hline AFRICA & $\begin{array}{c}-0.688 \\
(0.497)\end{array}$ & $\begin{array}{c}-1.355^{* * * *} \\
(0.381)\end{array}$ & $\begin{array}{c}-0.974 * * \\
(0.481)\end{array}$ & $\begin{array}{c}-1.325 * * * \\
(0.403)\end{array}$ & & & & \\
\hline
\end{tabular}


TABLE 2. Continued

\begin{tabular}{|c|c|c|c|c|c|c|c|c|}
\hline & \multicolumn{4}{|c|}{ Pooled negative binomial (PNB) } & \multicolumn{4}{|c|}{ HHG's fixed-effects negative binomial } \\
\hline & GTD DOM & GTD TRANS & ITERATE & ITER NAT. & GTD DOM & GTD TRANS & ITERATE & ITER NAT. \\
\hline AMERICA & $\begin{array}{c}0.529 \\
(0.459)\end{array}$ & $\begin{array}{c}-0.402 \\
(0.300)\end{array}$ & $\begin{array}{c}-0.370 \\
(0.310)\end{array}$ & $\begin{array}{c}-0.724 * * \\
(0.361)\end{array}$ & & & & \\
\hline MENA & $\begin{array}{c}0.159 \\
(0.389)\end{array}$ & $\begin{array}{c}0.018 \\
(0.385)\end{array}$ & $\begin{array}{c}0.404 \\
(0.415)\end{array}$ & $\begin{array}{l}1.116^{* * * *} \\
(0.398)\end{array}$ & & & & \\
\hline AsIA & $\begin{array}{c}-0.401 \\
(0.472)\end{array}$ & $\begin{array}{l}-1.231 * * * \\
(0.336)\end{array}$ & $\begin{array}{c}-0.915^{* *} \\
(0.410)\end{array}$ & $\begin{array}{l}-1.426 * * * * \\
(0.367)\end{array}$ & & & & \\
\hline Time Effects & No & No & No & No & Yes & Yes & Yes & Yes \\
\hline$N T$ & 892 & 892 & 892 & 892 & 877 & 835 & 847 & 774 \\
\hline
\end{tabular}

Notes: Cluster-robust (by country) and bootstrapped (100 replications) standard errors are in parentheses for pooled and fixed-effects models, respectively. NT is the sample size. ${ }^{*} p<.10$; $* * p<.05 ; * * * p<.01$. 


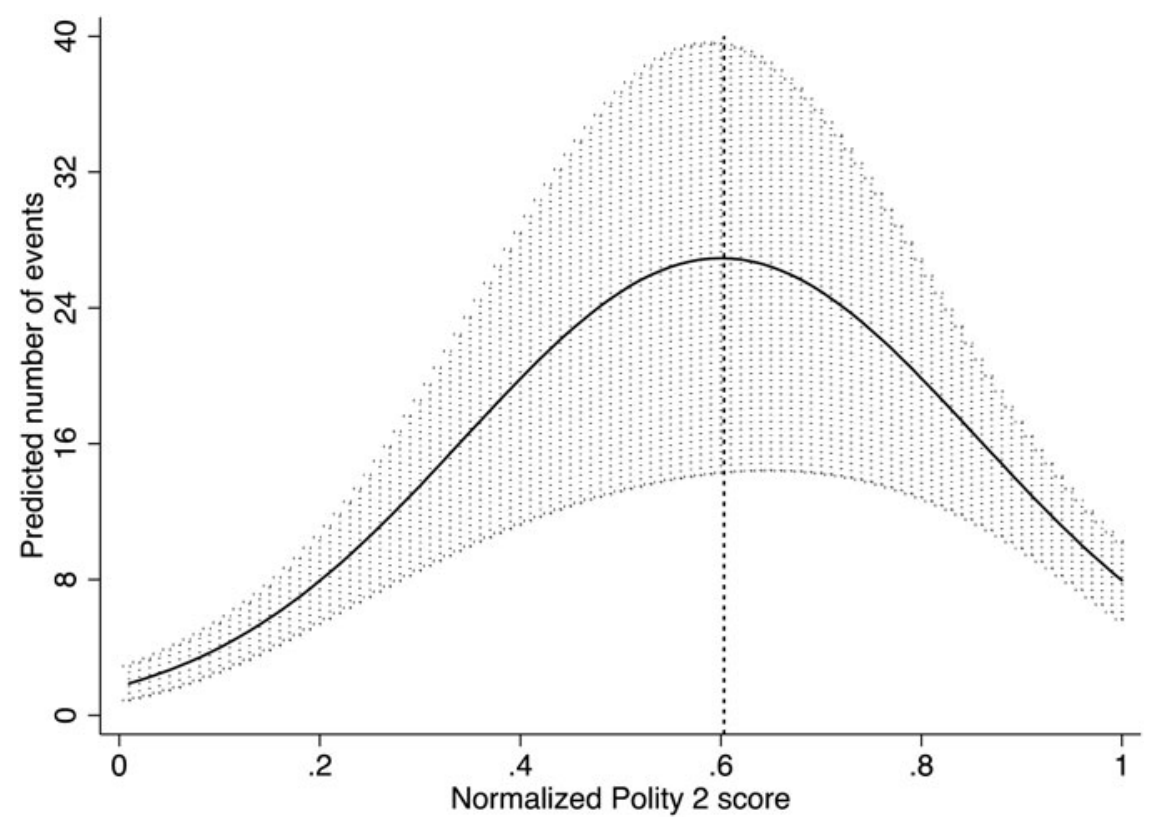

FIGURE 3. Predicted count of GTD transnational events (95\% CIs)

with anocracy being in between. For example, Chile (26.4), Mexico (15.2), and Pakistan (41.2) are sample countries with average normalized PoLITY 2 scores of between 0.57 and 0.67 , where the five-year averaged number of GTD transnational attacks is in parenthesis. Similarly, Belgium (9.7), Costa Rica (4.1), and the United States (28.6) have Polity scores of greater than 0.9, whereas Myanmar (1.7), Syria (6.1), and Uzbekistan (0.8) have Polity scores of less than 0.16 over the sample period. This suggests that anocracies are predicted to experience the largest number of attacks, ceteris paribus, as hypothesized. Our diagram also suggests why the bulk of previous studies found a positive relationship because fitting a line between very low attack values for strict autocracies and the mass of attacks for middle to middle-high democracies is likely to give an upward linear relationship.

Figure 4 presents the semi-elasticity of GTD transnational with respect to normalized Polity 2, which shows a percentage change in the expected count of terrorist attacks in response to a unit (0.01 point) increase in the normalized PoLITY 2 score. When the PoLiTy 2 score is less than 0.6 , the values of the semi-elasticity are positive, implying that as a country's Polity improves, the number of attacks increases. When the Polity 2 score exceeds 0.6, the values of semi-elasticity become negative, suggesting that the number of attacks reduces in response to an increase in POLITY 2 score. The semi-elasticity is 0 when the PoLITy 2 score reaches about 0.6 , which corresponds to the maximum predicted count of events in Figure 3. The conclusions for the other types of terrorism are similar and the graphs are given in online Appendix C. 


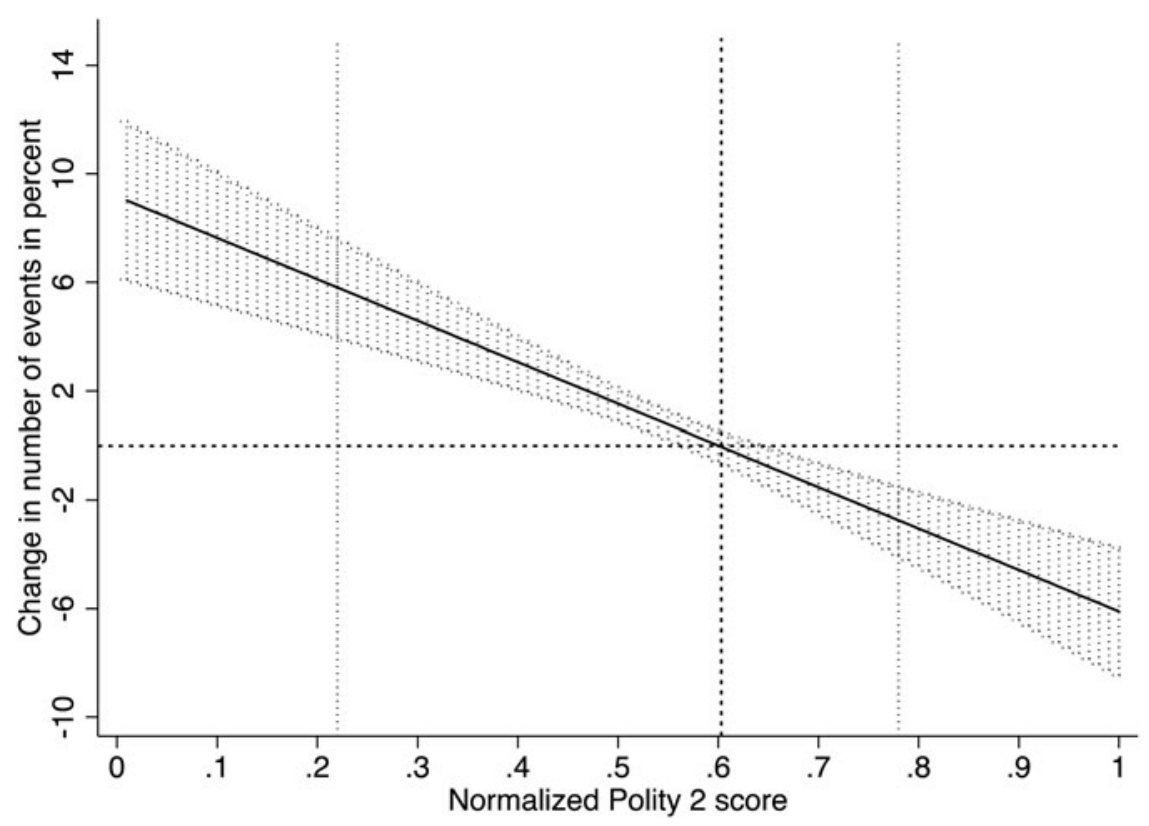

FIGURE 4. Semielasticity of GTD transnational with respect to Polity 2 (95\% CIs)

Among the control variables, civil war, discriminated population share, and population size have a positive effect on terrorist attacks. Alliance with the United States and participation in international crises induce a larger number of terrorist incidents. These variables are statistically significant across all PNB models. The effects of other variables are dependent on the type of terrorism. Location in Africa or Asia reduces the number of transnational attacks compared to location in Europe.

Second, we turn to the fixed-effects methods for count data. Columns 6 to 9 of Table 2 present the results of the fixed-effects negative binomial (FENB) estimator proposed by Hausman, Hall, and Griliches (referred to as HHG hereafter) ${ }^{75}$ All models confirm our main finding from the baseline regressions. The semi-elasticity plots also support our conclusion: as a country becomes more democratic, the number of terrorist attacks initially increases and then starts decreasing, indicative of an inverted U-shaped relationship between regime type and terrorism (available upon request). The impacts of participation in international crises, civil war, and economic globalization (ECON GLOBALIZATION) are consistent with the findings from the PNB regressions. The impact of population, however, is no longer robust. GDP PER CAPITA now becomes a statistically significant and positive determinant of terrorist events. 
Overall, we do not uncover evidence that more interventionist foreign policies have a significant robust effect on transnational terrorism. We find, however, that an involvement in foreign policy crises increases the number of domestic terrorist attacks. A potential explanation is that some of the country-specific and/or time-specific characteristics, which systematically affect terrorism, are correlated with foreign policy variables, resulting in upwardly biased coefficients. The magnitude of the coefficients for foreign policy variables reduces substantially when fixed effects are introduced. However, caution is needed with making such a conclusion. Foreign policy variables do not have much variation to begin with; zeros account for more than 70 percent of observations for these variables. Country fixed effects and time fixed effects reduce their variations even further, which may result in statistically insignificant coefficients.

\section{Robustness Analyses}

To rule out the possibility that our inverted U-shaped result is driven solely by civil war observations (see the literature review), we perform two robustness checks. First, we drop observations with positive civil conflict scores, and second, we drop all thirtytwo countries that experienced civil conflict(s) over the sample period. Our main results hold and are reported in online Appendix B (Table B2). Autocratic countries may either underreport terrorist incidents using strict media control ${ }^{76}$ or overstate the number of attacks to use the threat of terrorism as a pretext for suppressing dissent. We control for media freedom using data from Whitten-Woodring and Van Belle. ${ }^{77}$ Because previous studies controlled for regime change, ${ }^{78}$ we also add a dummy variable for regime transition to examine whether our results are explained by countries with recent regime changes, a characteristic of anocracies. The effects of these variables are not robust; the (categorical) media freedom variable is likely correlated with our regime transition variable. Nevertheless, our main results hold. ${ }^{79}$

Next, we investigate the sensitivity of our results to alternative estimation techniques. We estimate the standard (Pooled) OLS regression, which allows for a direct interpretation of the quadratic Polity term, by using a log of terrorist events (adding a small positive value to deal with zeros) as a dependent variable. Further, we implement the random-effects negative binomial regression. A key feature of the HHG's FENB estimator is that time-invariant variables can be estimated with this model, which is inconsistent with standard fixed-effects models. ${ }^{80}$ Therefore, we re-estimate Table 2, using the Poisson fixed-effects (PFE) estimator and the unconditional fixed-effects negative binomial (UFENB) estimator. Both regressions

76. See Drakos and Gofas 2006; and Sandler 1995.

77. Whitten-Woodring and Van Belle 2014.

78. See Li 2005; and Wilson and Piazza 2013.

79. Results available upon request.

80. See Allison and Waterman 2002; and Greene 2007. 
control for all unobservable and observable country-invariant and time-specific characteristics but the UFENB estimator suffers from the incidental parameter bias. Allison and Waterman performed simulations to show that the UFENB regression performs better than the PFE estimator; incidental parameter bias did not appear to be serious. ${ }^{81}$ As an additional check, we apply the UFENB estimator to an annual sample. Our annual sample period of more than thirty-five years gives us confidence that the bias is not a significant issue because the incidental parameter bias decreases as the number of time periods increases. Further, we add the lagged value of terrorism to control for persistence, while ameliorating the Nickell bias problem by using a large number of years. As a comparison, the population-averaged negative binomial (PANB) regression with robust standard errors and within-panel (equal) correlation structure, and the zero-inflated negative binomial model are also estimated for our main sample. Our main inverted U-shaped finding holds across all these methods. (See online Appendix B.)

For twenty-nine countries in our sample, which include most of the Western countries, the value of Poltry 2 does not change over time. Hence, the fixed-effects results demonstrate that our main finding is not sensitive to dropping these countries. We also perform a cross-sectional analysis over the whole sample period. The cross-sectional analysis allows us to examine whether a change in the regime type of an average country makes it more prone to terrorism relative to other countries in the long run. An inverted U-shaped relationship between regime type and terrorism holds for all but an ITERATE measure of terrorism (available upon request).

Finally, we examine the robustness of our main results to alternative measures of terrorism and regime type. First, we replace the number of terrorist incidents with the number of terrorist incidents with casualties for all four measures of terrorism. The casualty incidents' measure better captures the intensity of terrorist attacks. Second, to better understand the nonlinear relationship, we categorize the PoLiTy 2 index into three categories: autocracy, anocracy, and democracy (see the data section). We include dummy variables for autocracy and democracy with anocracy serving as a base category. Third, we replace the PoLITy 2 score with the Freedom House's measure of political rights. Fourth, we use the Vanhanen measure of political participation as an alternative proxy of regime type. Fifth, we include both the Vanhanen political participation measure and the executive constraint index. Tables 3 and 4 show the regime type results. The full results, including the findings of additional regressions, appear in online Appendix B.

Our main finding is generally confirmed with the number of terrorist events with casualties as a dependent variable in Table 3, using three estimators-HHG's FENB, UFENB, and PFE-though the PFE estimates are less accurate. The main results also hold if we use the PNB estimator (available upon request). With regard to the alternative measures of regime type, the effects of both democracy and autocracy are negative in both the PNB and the HHG's FENB regressions in Table 4. As a country 
TABLE 3. Using the number of terrorist incidents with casualties as a dependent variable

\begin{tabular}{|c|c|c|c|c|c|c|c|c|c|}
\hline & GTD DOM & GTD TRANS & ITERATE & GTD DOM & GTD TRANS & ITERATE & GTD DOM & GTD TRANS & ITERATE \\
\hline & \multicolumn{3}{|c|}{$H H G$ 's FENB } & \multicolumn{3}{|c|}{ UFENB } & \multicolumn{3}{|c|}{$P F E$} \\
\hline Polity 2 & $\begin{array}{l}6.089 * * * \\
(1.307)\end{array}$ & $\begin{array}{l}\text { 4.610*** } \\
(1.075)\end{array}$ & $\begin{array}{l}3.249 * * * \\
(1.070)\end{array}$ & $\begin{array}{l}6.985^{* * *} * \\
(2.560)\end{array}$ & $\begin{array}{l}5.178 * * * \\
(1.677)\end{array}$ & $\begin{array}{c}2.931^{*} \\
(1.597)\end{array}$ & $\begin{array}{l}7.453 * * * \\
(2.586)\end{array}$ & $\begin{array}{c}2.631 \\
(1.911)\end{array}$ & $\begin{array}{c}2.168 \\
(1.361)\end{array}$ \\
\hline PoLITy 2 SQRD & $\begin{array}{c}-4.933 * * * \\
(1.165)\end{array}$ & $\begin{array}{c}-3.780 * * * \\
(0.899)\end{array}$ & $\begin{array}{c}-2.703 * * * \\
(0.944)\end{array}$ & $\begin{array}{l}-6.731 \text { *** } \\
(2.077)\end{array}$ & $\begin{array}{c}-5.065^{* * * *} \\
(1.419)\end{array}$ & $\begin{array}{c}-3.220 * * \\
(1.320)\end{array}$ & $\begin{array}{c}-6.872 * * * \\
(1.958)\end{array}$ & $\begin{array}{c}-2.878 * * \\
(1.457)\end{array}$ & $\begin{array}{c}-2.307^{*} \\
(1.227)\end{array}$ \\
\hline$N T$ & 869 & 831 & 779 & 892 & 892 & 892 & 869 & 831 & 779 \\
\hline
\end{tabular}

Notes: Bootstrapped standard errors for the HHG's FENB, cluster-robust standard errors (clustered on country) for the UFENB, and robust standard errors for the PFE regressions are in parentheses. See Table 2 (columns $6-9$ ) for specifications. $* p<.10 ; * * p<.05 ; * * *<.01$. 
TABLE 4. Analysis of alternative measures of regime type

\begin{tabular}{|c|c|c|c|c|c|c|c|c|}
\hline Dependent Variable & AUTOCRACY & DEMOCRACY & FHPR & FHPR SQRD & $V P P$ & $V P P S Q R D$ & XCONST & $V P P$ \\
\hline & \multicolumn{2}{|c|}{$P N B$} & \multicolumn{2}{|c|}{$P N B$} & \multicolumn{2}{|c|}{$P N B$} & \multicolumn{2}{|c|}{$P N B$} \\
\hline GTD DOM & $\begin{array}{l}-1.485^{* * * *} \\
(0.292)\end{array}$ & $\begin{array}{c}-0.238 \\
(0.208)\end{array}$ & $\begin{array}{l}4.919 * * * \\
(1.430)\end{array}$ & $\begin{array}{l}-4.371 * * * \\
(1.357)\end{array}$ & $\begin{array}{c}2.687 * \\
(1.499)\end{array}$ & $\begin{array}{c}-2.814^{*} \\
(1.616)\end{array}$ & $\begin{array}{l}1.482 \text { *** } \\
(0.463)\end{array}$ & $\begin{array}{c}-0.445 \\
(0.633)\end{array}$ \\
\hline GTD TRANS & $\begin{array}{l}-1.515^{* * * *} \\
(0.244)\end{array}$ & $\begin{array}{c}-0.634 * * * \\
(0.164)\end{array}$ & $\begin{array}{l}3.214 * * * \\
(1.062)\end{array}$ & $\begin{array}{l}-2.896^{* * * *} \\
(0.985)\end{array}$ & $\begin{array}{c}1.921 \\
(1.287)\end{array}$ & $\begin{array}{c}-2.296 \\
(1.477)\end{array}$ & $\begin{array}{l}0.754 * * * \\
(0.287)\end{array}$ & $\begin{array}{c}-0.316 \\
(0.435)\end{array}$ \\
\hline ITERATE & $\begin{array}{l}-1.000 * * * \\
(0.284)\end{array}$ & $\begin{array}{c}-0.732 * * * \\
(0.201)\end{array}$ & $\begin{array}{l}2.914 * * * \\
(1.037)\end{array}$ & $\begin{array}{l}-2.674 * * * \\
(0.987)\end{array}$ & $\begin{array}{c}0.041 \\
(1.152)\end{array}$ & $\begin{array}{c}-0.689 \\
(1.241)\end{array}$ & $\begin{array}{c}0.133 \\
(0.295)\end{array}$ & $\begin{array}{c}-0.595 \\
(0.468)\end{array}$ \\
\hline ITER NAT. & $\begin{array}{l}-1.431 * * * \\
(0.260)\end{array}$ & $\begin{array}{c}-0.921 * * * \\
(0.258)\end{array}$ & $\begin{array}{l}4.172 * * * \\
(1.107)\end{array}$ & $\begin{array}{l}-3.749 * * * \\
(1.051)\end{array}$ & $\begin{array}{c}1.663 \\
(1.112)\end{array}$ & $\begin{array}{c}-2.132 * \\
(1.222)\end{array}$ & $\begin{array}{c}0.470 \\
(0.360)\end{array}$ & $\begin{array}{c}-0.362 \\
(0.489)\end{array}$ \\
\hline & \multicolumn{2}{|c|}{$H H G$ 's FENB } & \multicolumn{2}{|c|}{ HHG'S FENB } & \multicolumn{2}{|c|}{ HHG'S FENB } & \multicolumn{2}{|c|}{ HHG'S FENB } \\
\hline GTD DOM & $\begin{array}{c}-0.962 * * * \\
(0.160)\end{array}$ & $\begin{array}{c}-0.255^{*} \\
(0.149)\end{array}$ & $\begin{array}{l}3.380 * * * \\
(0.784)\end{array}$ & $\begin{array}{c}-3.079 * * * \\
(0.747)\end{array}$ & $\begin{array}{r}1.881 * \\
(0.973)\end{array}$ & $\begin{array}{c}-2.792 * * \\
(1.085)\end{array}$ & $\begin{array}{l}0.812 * * * \\
(0.272)\end{array}$ & $\begin{array}{c}-0.854 * * * \\
(0.330)\end{array}$ \\
\hline GTD TRANS & $\begin{array}{l}-0.823 * * * \\
(0.168)\end{array}$ & $\begin{array}{c}-0.108 \\
(0.159)\end{array}$ & $\begin{array}{l}2.935^{* * * *} \\
(0.775)\end{array}$ & $\begin{array}{c}-2.449 * * * \\
(0.774)\end{array}$ & $\begin{array}{l}2.920 \text { *** } \\
(0.963)\end{array}$ & $\begin{array}{l}-3.695 * * * \\
(1.042)\end{array}$ & $\begin{array}{l}0.858 * * * \\
(0.274)\end{array}$ & $\begin{array}{c}-0.574 \\
(0.376)\end{array}$ \\
\hline ITERATE & $\begin{array}{l}-0.590 * * * \\
(0.153)\end{array}$ & $\begin{array}{c}-0.140 \\
(0.137)\end{array}$ & $\begin{array}{c}1.663 * \\
(0.872)\end{array}$ & $\begin{array}{c}-1.482 * \\
(0.778)\end{array}$ & $\begin{array}{l}2.023 * * \\
(0.830)\end{array}$ & $\begin{array}{c}-2.265^{* * *} * \\
(0.796)\end{array}$ & $\begin{array}{c}0.358 \\
(0.235)\end{array}$ & $\begin{array}{c}-0.004 \\
(0.376)\end{array}$ \\
\hline ITER NAT. & $\begin{array}{l}-0.532 \text { *** } \\
(0.197)\end{array}$ & $\begin{array}{r}-0.295^{*} \\
(0.174)\end{array}$ & $\begin{array}{c}1.341 \\
(0.939)\end{array}$ & $\begin{array}{c}-1.247 \\
(0.871)\end{array}$ & $\begin{array}{c}1.047 \\
(1.159)\end{array}$ & $\begin{array}{c}-1.037 \\
(1.278)\end{array}$ & $\begin{array}{c}0.081 \\
(0.303)\end{array}$ & $\begin{array}{c}0.178 \\
(0.427)\end{array}$ \\
\hline
\end{tabular}

Notes: Cluster-robust standard errors (clustered on country) for the PNB and bootstrapped standard errors for the HHG's FENB regressions are in parentheses. See Table 2 (columns 6-9) for specifications. The dependent variables are shown in the rows and regime type variables— two in each regression-are reported in the columns. $* p<.10 ; * * p<.05 ; * * *<.01$. 
moves towards anocracy - either from autocracy or democracy-it experiences more terrorist attacks, consistent with our finding of a quadratic effect of regime type on terrorism. The effect is generally significant across regressions. ${ }^{82}$ Our fixed-effects results also generally hold if we use the Freedom House political rights (FHPR) score or Vanhanen political participation (VPP) measure-see Table 4. The exception is when ITERATE NAT, based on the perpetrators' nationality, is used as a dependent variable; the results become mostly insignificant. In the PNB regressions, the Freedom House index is significant across all models, while the Vanhanen political participation score is significant for domestic terrorism. To be consistent with Li's treatment of regime type, ${ }^{83}$ we conduct robustness estimations substituting the executive constraint (XCONST) from Polity and the Vanhanen participation indicator. Using these two indicators instead of the Polity index does not change the core results of the study. We do not include their quadratic terms because of high collinearity. The coefficient for executive constraint is mostly positive, whereas the estimate of political participation is negative, consistent with $\mathrm{Li}^{84}$ The estimates, however, are mostly insignificant. The exception is political participation, which is statistically significant across all fixed-effects models for domestic terrorism.

To account for Vreeland's ${ }^{85}$ contention that the aggregate POLITY 2 index may, in some cases, capture the latent influence of political instability and violence, we conduct two robustness checks. First, we use XCONST and its squared term. Second, we construct Vreeland's XPOLITY variable (and its squared term), which removes regulation of participation (PARREG) and the competitiveness of participation (PARCOMP) components of the POLITY variable. In both cases, our pooled and fixed-effects results generally hold. The exception is the fixed-effects finding when ITERATE is the dependent variable (available upon request). ${ }^{86}$

\section{Instrumental Variables Approach}

The Freedom House's measure of political rights in Table 4 presents an added benefit of ameliorating an endogeneity concern. Any reverse causality from terrorism to regime type mostly affects civil liberties. The political rights measure is immune from such effects insofar as it does not include the civil liberties component. Thus, the results that we obtained with Freedom House's measure of political rights are reassuring. Nevertheless, the omitted variables bias may still be an issue even though we control for fixed effects and numerous control variables. Further, the

82. We also replace the PoLity 2 variable with variables containing the restricted cubic spline of Polity 2 (with knots at $0.2,0.6$, and 0.75 , which correspond approximately to the cut-off points for autocracy, anocracy, and democracy) and the main results hold.

83. Li 2005.

84. Ibid.

85. Vreeland 2008

86. We do not investigate the costs and benefits of using an aggregated Polity index, or the questions surrounding aggregation method and the weights assigned to components. This important question deserves future research. 
polity measures potentially suffer from measurement error that-assuming it is a classical measurement error-leads to attenuation bias in the estimate of polity. To address these issues, we use the regional changes in Polity to capture the exogenous variation in a country's regime type ${ }^{87}$ First we construct a dummy variable for anocracy to measure a regime type (see data). ${ }^{88} \mathrm{Next}$, we follow Acemoglu and colleagues' procedure ${ }^{89}$ to construct an external instrument using waves of regional changes in regime types. The details appear in online Appendix B.

TABLE 5. Instrumental variables regressions

\begin{tabular}{|c|c|c|c|c|}
\hline & GTD DOM & GTD TRANS & ITERATE & ITER NAT. \\
\hline & \multicolumn{4}{|c|}{ Linear fixed-effects IV } \\
\hline ANOCRACY & $\begin{array}{l}7.071 * * * \\
(2.380)\end{array}$ & $\begin{array}{l}6.127 * * * \\
(2.013)\end{array}$ & $\begin{array}{l}3.643^{* *} \\
(1.456)\end{array}$ & $\begin{array}{c}1.374 \\
(1.458)\end{array}$ \\
\hline \multirow[t]{2}{*}{$N T$} & 883 & 883 & 883 & 883 \\
\hline & \multicolumn{4}{|c|}{ Poisson control function } \\
\hline ANOCRACY & $\begin{array}{l}5.045^{* *} \\
(2.174)\end{array}$ & $\begin{array}{l}2.909 * * \\
(1.214)\end{array}$ & $\begin{array}{l}2.886^{* *} * \\
(1.202)\end{array}$ & $\begin{array}{c}0.345 \\
(1.289)\end{array}$ \\
\hline RESIDUAL $1 \mathrm{ST}$ & $-4.184 * *$ & -1.733 & -1.783 & 0.809 \\
\hline STAGE & (2.092) & (1.159) & (1.190) & $(1.299)$ \\
\hline$N T$ & 884 & 884 & 884 & 884 \\
\hline
\end{tabular}

Notes: Cluster-robust standard errors, clustered on country, are in parentheses. See the online Appendix B for complete results. $* p<.10 ; * * p<.05 ; * * * p<.01$.

We begin by using a log of terrorist incidents (adding a positive value to deal with zeros) as a dependent variable. This allows us to implement a standard fixed-effects, two-stage least square regression. Next, we implement the pooled Poisson instrumental variables regression using the control function method. ${ }^{90}$ The Kleibergen-Paap rk LM statistic strongly rejects the null hypothesis, suggesting that the instrument is correlated with the endogenous variable. Moreover, the Kleibergen-Paap rk Wald $F$-statistic confirms that the instrument is strong. The neighboring (regional) anocracy is a significant and positive determinant of a country's anocracy in the first-stage regressions. However, the estimates of the first-stage residual in the second-stage Poisson regression are significant for domestic terrorism only. The estimates of anocracy are positive and mostly statistically significant, suggesting that anocracies experience more terrorism than either democracies or autocracies. This supports our main findings. Table 5 shows the results of the main variables. The full results are reported in online Appendix B.

87. Acemoglu et al. 2015.

88. We could not use POLITY 2 and its squared term because it would require two instruments and create a multicollinearity issue.

89. Acemoglu et al. 2015.

90. Cameron and Trivedi 2013. For the Poisson regressions, time dummy variables are included but not country fixed effects owing to convergence issues, although the results of the log-linear fixed-effects regressions are encouraging. 
Our identification strategy is based on the assumption that neighboring regime changes spill over to other countries in the region but they have no direct impact on a country's terrorism for the excludability condition to hold. That is, once the various regressors are controlled for, the systematic impact of the regional regime types on a country's terrorism channels through the country's own regime type. One might argue that regime changes are systematically associated with instability and terrorism that spill over to neighboring countries, thereby affecting the validity of our instrument. However, we did not uncover any systematic relationship between regime transition and terrorism. Nevertheless, to address this concern, we construct a neighbor's conflict variable using conflict information in contiguous countries. If more than one bordering country is experiencing instability, we record the conflict with the largest magnitude to be on the conservative side. We re-run our instrumental variables regressions by directly controlling for conflicts in neighboring countries and our results hold (available upon request). This increases our confidence that our findings are robust.

\section{Concluding Remarks}

Regime type exerts an inverted U-shaped relationship on alternative forms of terrorism. Strict autocracies and full-fledged democracies are much less plagued by terrorism than anocracies. This relationship is shown to be incredibly robust, holding for myriad alternative empirical models. Moreover, the relationship holds for domestic and transnational terrorism. In the transnational case, the inverted U-shaped relationship characterizes terrorism based on the venue country and the origin country of the perpetrators. The inverted U-shaped relationship generally holds for other regime measures such as Freedom House political rights and the Vanhanen political participation measure. Although our result agrees with a handful of articles, it disagrees with the bulk of the terrorism literature that found a positive or no relationship. Moreover, our study addresses alternative terrorism measures, alternative regime measures, two event data sets, and extended time periods, unlike the few studies that found an inverted U-shaped relationship. A noteworthy finding is that foreign policy variables do not affect terrorism when country-specific and time-specific fixed effects are taken into account.

The international community must consider the likely rise in terrorism in countries that transition to anocracies on their way to democracies. This is particularly germane for recent high-profile attacks. For instance, the June and July 2016 attacks in Turkey and Bangladesh, respectively, took place in anocracies that have not transitioned to full, stable democracies. One attacker in the Istanbul airport attack was generally reported as having been from an anocracy-Kyrgyzstan. Western efforts to foster democracies from autocracies must be combined with vigilance regarding increased terrorism.

\section{Supplementary Material}

Supplementary material for this article is available at <https://doi.org/10.1017/ S0020818317000169>. 


\section{References}

Abadie, Alberto. 2006. Poverty, Political Freedom and the Roots of Terrorism. American Economic Review 96 (2):50-6.

Acemoglu, Daron, Suresh Naidu, Pascual Restrepo, and James A. Robinson. 2015. Democracy Does Cause Growth. Working paper. Available at <http://economics.mit.edu/faculty/acemoglu/paper>. Accessed 11 May 2015.

Aksoy, Deniz, and David B. Carter. 2014. Electoral Institutions and the Emergence of Terrorist Groups. British Journal of Political Science 44 (1):181-204.

Aksoy, Deniz, David B. Carter, and Joseph Wright. 2012. Terrorism in Dictatorships. The Journal of Politics 74 (3):810-26.

Allison, Paul D., and Richard P. Waterman. 2002. Fixed-effects Negative Binomial Regression Models. Sociological Methodology 32 (1):247-65.

Bandyopadhyay, Subhayu, and Javed Younas. 2011. Poverty, Political Freedom, and the Roots of Terrorism in Developing Countries: An Empirical Assessment. Economics Letters 112 (2):171-75.

Cameron, A. Colin, and Pravin K. Trivedi. 2013. Regression Analysis of Count Data. New York: Cambridge University Press.

Cederman, Lars-Erik, Simon Hug, and Lutz F. Krebs. 2010. Democratization and Civil War: Empirical Evidence. Journal of Peace Research 47 (4):377-94.

Chenoweth, Erica. 2010. Democratic Competition and Terrorist Activity. The Journal of Politics 72 (1): 16-30.

2013. Terrorism and Democracy. Annual Review of Political Science 16 (1):355-78.

Conrad, Courtenay R., Justin Conrad, and Joseph K. Young. 2014. Tyrants and Terrorism: Why Some Autocrats Are Terrorized While Others Are Not. International Studies Quarterly 58 (3):539-49.

Doyle, Michael W. 1997. Ways of War and Peace. New York: W.W. Norton and Co.

Dragu, Tiberiu. 2011. Is There a Trade-off between Security and Liberty? Executive Bias, Privacy Protections, and Terrorism Prevention. American Political Science Review 105 (1):64-78.

Drakos, Konstantinos, and Andreas Gofas. 2006. In Search of the Average Transnational Terrorist Attack Venue. Defence and Peace Economics 17 (2):73-93.

Dreher, Axel. 2006. Does Globalization Affect Growth? Empirical Evidence from a New Index. Applied Economics 38 (10):1091-110.

Dreher, Axel, and Justina A.V. Fischer. 2010. Government Decentralization As a Disincentive for Transnational Terror? An Empirical Analysis. International Economic Review 51 (4):981-1002.

Dreher, Axel, Noel Gaston, and Pim Martens. 2008. Measuring Globalisation: Gauging Its Consequence. New York: Springer.

Enders, Walter, Gary A. Hoover, and Todd Sandler. 2016. The Changing Nonlinear Relationship Between Income and Terrorism. Journal of Conflict Resolution 60 (2):195-225.

Enders, Walter, Todd Sandler, and Khusrav Gaibulloev. 2011. Domestic Versus Transnational Terrorism: Data, Decomposition and Dynamics. Journal of Peace Research 48 (3):319-37.

Eubank, William L., and Leonard Weinberg. 1994. Does Democracy Encourage Terrorism? Terrorism and Political Violence 6 (4):417-35.

Eyerman, Joe. 1998. Terrorism and Democratic States: Soft Targets or Accessible Systems. International Interactions 24 (2):151-70.

Fearon, James. 2003. Ethnic and Cultural Diversity by Country. Journal of Economic Growth 8 (2):195-222.

Findley, Michael G., and Joseph K. Young. 2012. Terrorism and Civil War: A Spatial and Temporal Approach to a Conceptual Problem. Perspectives on Politics 10 (2):285-305.

Freedom House. 2014. Freedom in the World: Aggregate and Subcategory Scores. Available at <https:// freedomhouse.org/report/freedom-world-aggregate-and-subcategory-scores\#>. Accessed 21 July 2014.

Gaibulloev, Khusrav, and Todd Sandler. 2014. An Empirical Analysis of Alternative Ways That Terrorist Groups End. Public Choice 160 (1-2):25-44. 
Gassebner, Martin, and Simon Luechinger. 2011. Lock, Stock, and Barrel: A Comprehensive Assessment of the Determinants of Terror. Public Choice 149 (3-4):235-61.

Gibler, Douglas M. 2009. International Military Alliances, 1648-2008. Washington, DC: CQ Press.

Greene, William. 2007. Functional Form and Heterogeneity in Models for Count Data. Foundations and Trends in Econometrics 1 (2):113-218.

Hamilton, Lawrence C., and James D. Hamilton. 1983. Dynamics of Terrorism. International Studies Quarterly 27 (1):39-54.

Hausman, Jerry, Brownyn H. Hall, and Zvi Griliches. 1984. Econometric Models for Count Data with an Application to the Patents-R \& D Relationship. Econometrica 52 (4):909-38.

Hegre, Håvard, Tanja Ellingsen, Scott Gates, and Nils Petter Gleditsch. 2001. Toward a Democratic Civil Peace? Democracy, Political Change, and Civil War, 1816-1992. American Political Science Review 95 (1):33-48.

Hoffman, Bruce. 2006. Inside Terrorism. Revised Edition. New York: Columbia University Press.

Kisangani, Emizet N.F., and Jeffrey Pickering. 2008. International Military Interventions, 1989-2005. Inter-University Consortium for Political and Social Research (ICPSR). Available at $<$ http://www.kstate.edu/polsci/intervention/>. Accessed 21 July 2014.

Kurrild-Klitgaard, Peter, Mogens K. Justesen, and Robert Klemmensen. 2006. The Political Economy of Freedom, Democracy, and Transnational Terrorism. Public Choice 128 (1-2):289-315.

Lai, Brian. 2007. Draining the Swamp: An Empirical Examination of the Production of International Terrorism. Conflict Management and Peace Science 24 (4):297-310.

Li, Quan. 2005. Does Democracy Produce or Reduce Transnational Terrorist Incidents? Journal of Conflict Resolution 49 (2):278-97.

Li, Quan, and Drew Schaub. 2004. Economic Globalization and Transnational Terrorism. Journal of Conflict Resolution 48 (2):230-58.

Marshall, Monty G. 2015. Major Episodes of Political Violence (MEPV) and Conflict Regions, 1946-2014. Center for Systemic Peace. Available at <http://www.systemicpeace.org/inscrdata.html>. Accessed 12 February 2016.

Marshall, Monty G., and Ted Robert Gurr. 2003. Peace and Conflict 2003: A Global Survey of Armed Conflicts, Self-Determination Movements and Democracy. College Park, MD: Center for International Development and Conflict Management (CIDCM).

Marshall, Monty G., Ted Robert Gurr, and Keith Jaggers. 2014. Polity IV Dataset Version 2013 and Dataset Users' Manual. Center for Systemic Peace. Available at <http://www.systemicpeace.org/ inscrdata.html>. Accessed 14 June 2014.

Mickolus, Edward F., Todd Sandler, Jean M. Murdock, and Peter Flemming. 2014. International Terrorism: Attributes of Terrorist Events, 1968-2013 (ITERATE). Ponte Vedra, FL: Vinyard Software.

National Consortium for the Study of Terrorism and Responses to Terrorism (START). 2014. Global Terrorism Database (GTD). Available at <www.start.umd.edu/gtd/>. Accessed 14 June 2014.

Pape, Robert A. 2003. The Strategic Logic of Suicide Terrorism. American Political Science Review 97 (3): 343-61.

Pearson, Frederic S., and Robert A. Bauman. 1993. International Military Interventions, 1946-1948. International Consortium for Political and Social Research. Available at <http://www.k-state.edu/ polsci/intervention/>. Accessed 21 July 2014.

Piazza, James A. 2007. Draining the Swamp: Democracy Promotion, State Failure, and Terrorism in Nineteen Middle Eastern Countries. Studies in Conflict and Terrorism 30 (6):521-39.

. 2008. Do Democracy and Free Markets Protect Us from Terrorism? International Politics 45 (1): 72-91.

Ross, Jeffrey Ian. 1993. Structural Causes of Oppositional Political Terrorism: Towards a Causal Model. Journal of Peace Research 30 (3):317-29.

San-Akca, Belgin. 2014. Democracy and Vulnerability: An Exploitation Theory of Democracies by Terrorists. Journal of Conflict Resolution 58 (7):1285-310.

Sandler, Todd. 1995. On the Relationship Between Democracy and Terrorism. Terrorism and Political Violence 7 (4):1-9. 
Savun, Burcu, and Brian J. Phillips. 2009. Democracy, Foreign Policy, and Terrorism. Journal of Conflict Resolution 53 (6):878-904.

Schmid, Alex. 1992. Terrorism and Democracy. Terrorism and Political Violence 4 (4):14-25.

Singer, David. 1987. Reconstructing the Correlates of War Dataset on Material Capabilities of States, 1816-1985. International Interactions 14 (2):115-32.

Singer, David, Stuart Bremer, and John Stuckey. 1972. Capability Distribution, Uncertainty, and Major Power War, 1820-1965. In Peace, War, and Numbers, edited by Bruce Russett, 19-48. Beverly Hills, CA: Sage.

Siqueira, Kevin, and Todd Sandler. 2006. Terrorists Versus the Government: Strategic Interaction, Support, and Sponsorship. Journal of Conflict Resolution 50 (2):218-36.

Testas, Abdelaziz. 2004. Determinants of Terrorism in the Muslim World: An Empirical Cross-Sectional Analysis. Terrorism and Political Violence 16 (2):253-73.

US Department of Homeland Security. 2011. Risk Management Fundamentals-Homeland Security Risk Management Doctrine. Available at $<$ http://www.dhs.gov/sites/default/files/publications/rma-risk-management-fundamentals.pdf $>$. Accessed 15 August 2015.

Valentino, Benjamin A., Paul K. Huth, and Sarah E. Croco. 2010. Bear Any Burden? How Democracies Minimize the Costs of War. Journal of Politics 72 (2):528-44.

Vanhanen, Tatu, and Krister Lundell. 2014. Measures of Democracy 1810-2012, version 6.0. Available at <https://www.prio.org/Data/Governance/Vanhanens-index-of-democracy/>. Accessed 21 July 2014.

Vreeland, James R. 2008. The Effect of Political Regime on Civil War: Unpacking Anocracy. Journal of Conflict Resolution 52 (3):401-25.

Wade, Sara J., and Daniel Reiter. 2007. Does Democracy Matter? Regime Type and Suicide Terrorism. Journal of Conflict Resolution 51 (2):329-48.

Weeks, Jessica L. 2008. Autocratic Audience Costs: Regime Type and Signaling Resolve. International Organization 62 (1):35-64.

Whitten-Woodring, Jenifer, and Douglas A. Van Belle. 2014. Historical Guide to World Media Freedom: A Country-by-Country Analysis. Thousand Oaks, CA: CQ Press.

Wilkenfeld, Jonathan, Michael Brecher, Joseph Hewitt, Kyle Beardsley, and Pelin Eralp. 2010. International Crisis Behavior Datasets, version 10 (1918-2007), Center for International Development and Conflict Management, University of Maryland. Available at <https://sites.duke.edu/icbdata/data-collections/>. Accessed 21 July 2014.

Wilkinson, Paul. 1986. Terrorism and the Liberal State. Revised Edition. London, UK: Macmillan.

Wilson, Matthew C., and James A. Piazza. 2013. Autocracies and Terrorism: Conditioning Effects of Authoritarian Regime Type on Terrorist Attacks. American Journal of Political Science 57 (4):941-55.

Wimmer, Andreas, Lars-Erik Cederman, and Brian Min. 2009. Ethnic Politics and Armed Conflict: A Configurational Analysis of a New Global Dataset. American Sociological Review 74 (2):316-37.

World Bank. 2014. World Development Indicators (WDI). Available at <http://data.worldbank.org/datacatalog/world-development-indicators>. Accessed 8 July 2014. 